\title{
Review \\ Impact of Hydrolysis, Acetylation or Succinylation on Functional Properties of Plant-Based Proteins: Patents, Regulations, and Future Trends
}

\author{
Georgina L. Heredia-Leza ${ }^{1}$, Luz María Martínez ${ }^{1}$ (D) and Cristina Chuck-Hernandez ${ }^{2, *(D)}$ \\ 1 Escuela de Ingeniería y Ciencias, Tecnológico de Monterrey, Ave. Eugenio Garza Sada 2501, \\ Monterrey 64849, Mexico; A01282171@itesm.mx (G.L.H.-L.); luzvidea@tec.mx (L.M.M.) \\ 2 Instituto para la Investigación en Obesidad, Tecnologico de Monterrey, Ave. Eugenio Garza Sada 2501, \\ Monterrey 64849, Mexico \\ * Correspondence: cristina.chuck@tec.mx
}

check for updates

Citation: Heredia-Leza, G.L.;

Martínez, L.M.; Chuck-Hernandez, C. Impact of Hydrolysis, Acetylation or Succinylation on Functional

Properties of Plant-Based Proteins:

Patents, Regulations, and Future

Trends. Processes 2022, 10, 283.

https://doi.org/10.3390/pr10020283

Academic Editors: Adriana Paucean and Vlad Mureşan

Received: 28 December 2021

Accepted: 18 January 2022

Published: 31 January 2022

Publisher's Note: MDPI stays neutral with regard to jurisdictional claims in published maps and institutional affiliations.

Copyright: (C) 2022 by the authors. Licensee MDPI, Basel, Switzerland. This article is an open access article distributed under the terms and conditions of the Creative Commons Attribution (CC BY) license (https:// creativecommons.org/licenses/by/ $4.0 /)$.

\begin{abstract}
Nowadays, plant-based proteins are gaining momentum due to their wide availability, good amino acid content, and their market appeal. Unfortunately, these molecules usually have low water solubility, affecting other functional characteristics, such as foaming and emulsification, opening technological opportunities for research. Some plant-based protein applications rely on adjustments to final formulations and changing these chemical structures to produce new protein ingredients is also a path widely used in recent research. These modifications can be classified as physical or chemical, the latter being the most popular, and hydrolysis is one of the more widely reported modifications. This review explores the application of chemical modifications to plant-based proteins to improve techno-functional properties, when applied as part of food formulations. In addition, acetylation and succinylation, as the second and third most used processes, are discussed, including a deep analysis of their effects. Furthermore, since there is no concise compilation of patents associated with these technological efforts, some of the references that involve chemical modifications and current regulations used worldwide for novel foods produced with these technologies are included in this review. Finally, future perspectives for the chemical modification of proteins are discussed.
\end{abstract}

Keywords: plant-based proteins; chemical modification; acetylation; succinylation; enzymatic hydrolysis

\section{Introduction}

Proteins are the most common macromolecules present in humans, and they have several functions [1]. They can be structural components, hormones, messengers, enzymes, transporters, components of the immune system, etc. [1]. There are four categories into which the protein structure is divided: primary, secondary, tertiary, and quaternary; proteins are also classified into two main groups based on their functions, structural (the principal components of tissues) and biologically active proteins (hormones and enzymes can be found in this category) [2]. Dietary protein represents the primary source of amino acids, which are necessary for the stages of growth, development, and, in general, for keeping humans healthy [3]. Therefore, the recommended amount of protein from animal or plant sources that should be acquired daily through diet is $0.83 \mathrm{~g} / \mathrm{kg}[4,5]$. As shown in Figure 1, based on their origin, plant-based proteins can be classified into the following groups: cereals, legumes, oilseeds, nuts, edible seeds, tubers, and other sources, such as lignocellulosic material.

One thing to consider is that the protein contents of these categories vary. Still, the highest percentage can be found in oil seeds and nuts, with approximately $25.8 \%$ and $20.0 \%$ of their weights, respectively [6,7]. 


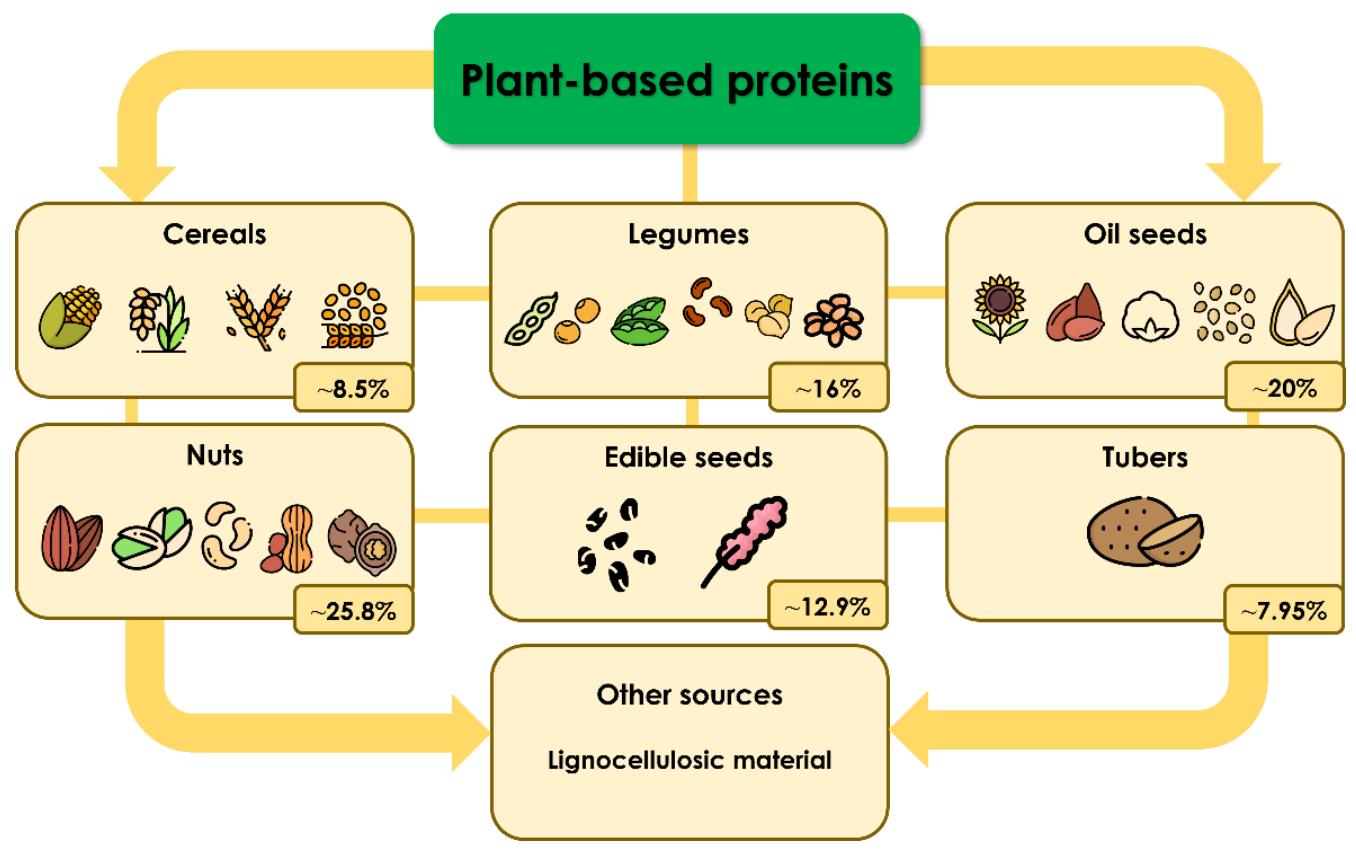

Figure 1. Classification of plant-based proteins and their average protein content. Protein data were obtained from [6-12].

The worldwide value of the protein as ingredients market in 2021 was equivalent to 55.7 billion U.S. dollars, and it is expected to reach 70.9 billion U.S. dollars by 2025 [13]. Moreover, the plant-based protein market accounts for 11 billion U.S. dollars, and it is projected to reach 14.6 billion U.S. dollars by 2025 [14].

It should be noted that although vegetal sources are rich in protein, consumption from animal sources is preferred for two main reasons: their amino acid composition (which helps to maintain muscle mass) and the ease with which they are digested by humans [15-17].

Due to their low water solubility, at most $33 \%$ of high-protein ingredients derived from plant proteins are used in end food applications [18]. Other functional properties, such as foam and emulsifying capacity, are important when producing foods and rely on solubilityTherefore, the latter becomes one of the most important traits of plant-based proteins. Several strategies have been devised in the food industry sector to increase solubility, among these are structural modifications of the protein chain, which can be classified as enzymatic, physical, and also chemical, or based on a chemical reaction where one or more functional groups of the original protein is changed [18,19]. The modification of proteins (with sources such as canola, mung bean, and lentil) has enhanced their functional properties [20-22].

This review will discuss the most reported chemical modification (acetylation, succinylation, and enzymatic hydrolysis) of plant-based proteins and their effects on solubility, emulsifying capacity, and foam capacity, as these are the most important functionalities for food development using new ingredients. These functionalities represent the interaction of proteins with water, oil, and air and modulate the texture, taste, and other sensory properties of foods. In addition, the effect of these modifications on the nutritional properties of plant-based proteins will be mentioned. Furthermore, some patents and the relevance of modified plant-based proteins in industrial processes will also be addressed. Finally, a general outlook will be given on the importance of these modifications and future trends.

\section{Effect of Chemical Modifications on the Solubility, Emulsifying Capacity, Foam Capacity, and Nutritional Properties of Plant-Based Proteins}

Chemical modification refers to manipulating certain functional groups of a protein, or its molecular structure, using a chemical reaction to enhance their bioactivity and properties, 
such as solubility, emulsifying capacity, and foaming capacity [12]. The most common chemical modifications used for protein processing are acetylation and succinylation [21], and one of the most explored, to improve solubility is enzymatic hydrolysis. Enzymatic hydrolysis also improves other functionalities, such as foam and emulsion stabilization. It has been used to produce bioactive or functional peptides as antioxidants and inhibitors of the angiotensin-converting enzyme (ACE) [18].

The three general reactions of acetylation, succinylation, and hydrolysis are presented in Figure 2A-C.

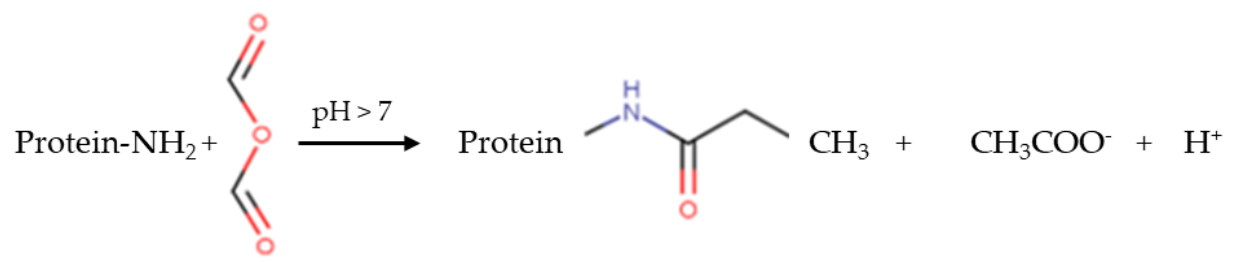

(A)

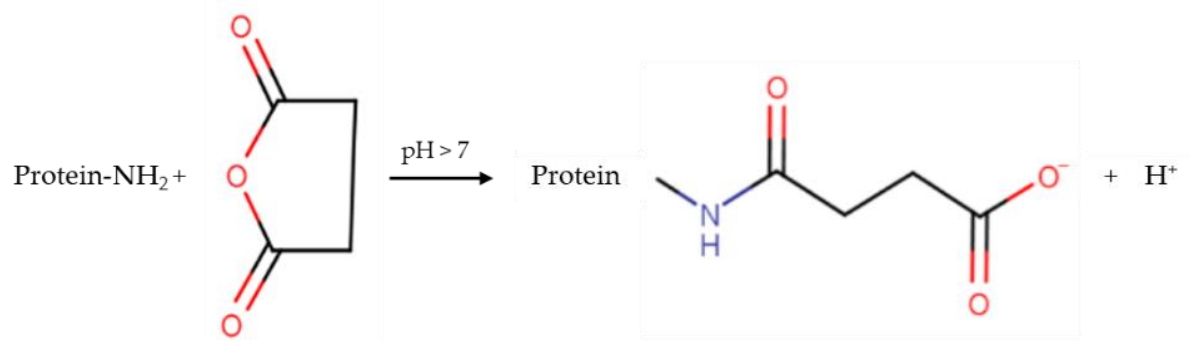

(B)<smiles>[R]C(C(=O)NC(=O)O)N([2H])C(=O)C([R])(C)C</smiles>

Peptide<smiles>[R]C(C(=O)O)C(C)C</smiles>

(C)<smiles>[R]C(N)C(=O)O</smiles>

Amino acid

Figure 2. Schematic representation of the main chemical protein modification reactions. (A) Acetylation, (B) succinylation and (C) hydrolysis.

Acetylation is achieved by adding acetyl groups to protein amino groups in a covalent way, and is generally performed using acetic anhydride as a reagent [23]. Hydrophilic groups, such as hydroxyl, $\varepsilon$-amino group, and phenol, are susceptible to acetylation [21].

Succinylation can be done by adding succinic anhydride; this incorporates succinyl groups into a protein [24]. Through this reaction, a positive to negative charge substitution occurs in lysine residues [25]. In contrast, enzymatic hydrolysis can be defined as a process achieved using an acid, an enzyme, or a base, producing a hydrolysate composed of peptides and amino acids [26].

These three reactions have been used to modify plant-based protein structures, so that they can be used as food ingredients; previous works are described in Table 1, along with their functional properties (solubility, emulsifying capacity, and foam capacity). 
Table 1. Previous works on acetylation, succinylation, and hydrolysis of plant-based proteins and their functional properties **

\begin{tabular}{|c|c|c|c|c|c|c|c|c|c|c|c|}
\hline $\begin{array}{l}\text { Protein } \\
\text { Source }\end{array}$ & Reaction & $\begin{array}{l}\text { Optimal Conditions } \\
\text { for Enhanced } \\
\text { Solubility } \\
\text { (\% of Modification } \\
\text { or Amount of } \\
\text { Chemical Agent, } \\
\text { Enzyme IA, pH) }\end{array}$ & \multicolumn{2}{|c|}{ Solubility $^{a}$} & $\begin{array}{l}\text { Optimal Conditions } \\
\text { for Enhanced } \\
\text { Emulsifying Activity } \\
\text { (\% of Modification or } \\
\text { Amount of Chemical } \\
\text { Agent, Enzyme IA, } \\
\text { pH) }\end{array}$ & \multicolumn{2}{|c|}{ Emulsifying Activity ${ }^{a}$} & $\begin{array}{c}\text { Optimal } \\
\text { Conditions for } \\
\text { Enhanced Foam } \\
\text { Capacity } \\
\text { (\% of } \\
\text { Modification, } \\
\text { pH, and } \\
\text { Enzyme IA) }\end{array}$ & \multicolumn{2}{|c|}{ Foam Capacity $^{a}$} & Ref. \\
\hline \multirow{2}{*}{ Canola } & Acetylation & $26 \%, 9$ & \multirow{2}{*}{$65.94 \%{ }^{\mathrm{b}}$} & $77.8 \%$ & $16 \%$ & \multirow{2}{*}{$39.8 \%$} & $75.6 \%$ & $62 \%$ & \multirow{2}{*}{$43.3 \%$} & $189.7 \%$ & \multirow{2}{*}{ [20] } \\
\hline & Succinylation & $3 \%, 8$ & & $82.5 \%$ & $61 \%$ & & $100 \%$ & $61 \%$ & & $158 \%$ & \\
\hline \multirow{2}{*}{ Mung bean } & Acetylation & $\begin{array}{l}0.6 \mathrm{~g} \text { of acetic } \\
\text { anhydride/g of } \\
\text { protein }\end{array}$ & \multirow{2}{*}{$62.42 \%$} & $85.42 \%$ & $\begin{array}{c}0.2 \mathrm{~g} \text { of acetic } \\
\text { anhydride/g of protein }\end{array}$ & \multirow{2}{*}{$65 \%$} & $65 \%$ & $\begin{array}{l}0.2 \mathrm{~g} \text { of acetic } \\
\text { anhydride/g of } \\
\text { protein }\end{array}$ & \multirow{2}{*}{$110.35 \%$} & $135.33 \%$ & \multirow{2}{*}{ [21] } \\
\hline & Succinylation & $\begin{array}{l}1 \mathrm{~g} \text { of succinic } \\
\text { anhydride/g of } \\
\text { protein }\end{array}$ & & $93.43 \%$ & $\begin{array}{c}0.2 \mathrm{~g} \text { of succinic } \\
\text { anhydride/g of protein }\end{array}$ & & $62 \%$ & $\begin{array}{l}0.2 \mathrm{~g} \text { of succinic } \\
\text { anhydride/g of } \\
\text { protein }\end{array}$ & & $129.5 \%$ & \\
\hline Lentil & Acetylation & $62.5 \%, 8$ & $100.15 \%$ & $100.36 \%$ & $\begin{array}{c}\text { Acetylation degree of } \\
62.5 \%\end{array}$ & $54.2 \%$ & $56 \%$ & $62.5 \%, 4$ & $88 \mathrm{~mL}^{\mathrm{c}}$ & $90 \mathrm{~mL}$ & {$[22]$} \\
\hline \multirow{2}{*}{$\begin{array}{l}\text { Bambara } \\
\text { groundnut }\end{array}$} & Acetylation & $78 \%, 12$ & \multirow{2}{*}{$90.77 \%{ }^{d}$} & $93.85 \%$ & \multirow{2}{*}{$\mathrm{pH}$ of 10} & \multirow{2}{*}{$77.26 \% \mathrm{e}^{\mathrm{e}}$} & $80.21 \%$ & $\mathrm{pH}$ of 10 & \multirow{2}{*}{$219.8 \mathrm{~mL}^{\mathrm{e}}$} & $227.76 \mathrm{~mL}$ & \multirow{2}{*}{ [25] } \\
\hline & Succinylation & $72 \%, 12$ & & $97.95 \%$ & & & $80.63 \%$ & $\mathrm{pH}$ of 10 & & $232.65 \mathrm{~mL}$ & \\
\hline Mucuna bean & Succinylation & $\begin{array}{l}0.5 \mathrm{~g} \text { of succinic } \\
\text { anhydride/g of } \\
\text { protein, } 12\end{array}$ & $92.42 \% \mathrm{~d}$ & $98.03 \%$ & $\mathrm{pH}$ of 10 & $71.58 \%{ }^{f}$ & $76.87 \%$ & & $\mathrm{~N} / \mathrm{A}$ & & [27] \\
\hline \multirow{2}{*}{ Cowpea } & Acetylation & $\begin{array}{c}0.25, \mathrm{~g} \text { of acetic } \\
\text { anhydride/g of } \\
\text { protein, } 7\end{array}$ & \multirow{2}{*}{$38 \% \mathrm{~g}$} & $89.5 \%$ & $\begin{array}{c}0.25 \mathrm{~g} \text { of acetic } \\
\text { anhydride/g of protein }\end{array}$ & \multirow{2}{*}{0.26} & 0.56 & $\begin{array}{c}0.5 \mathrm{~g} \text { of acetic } \\
\text { anhydride } / \mathrm{g} \\
\text { of protein }\end{array}$ & \multirow{2}{*}{$66 \%$} & $88 \%$ & \multirow{2}{*}{ [28] } \\
\hline & Succinylation & $\begin{array}{l}0.25, \mathrm{~g} \text { of succinic } \\
\text { anhydride/g of } \\
\text { protein, } 7\end{array}$ & & $84.44 \%$ & $\begin{array}{l}0.75 \mathrm{~g} \text { of succinic } \\
\text { anhydride/g of protein }\end{array}$ & & 0.52 & $\begin{array}{c}0.25 \mathrm{~g} \text { of } \\
\text { suc-cinic } \\
\text { anhydride/g of } \\
\text { protein }\end{array}$ & & $116.36 \%$ & \\
\hline Pumpkin & Acetylation & $\begin{array}{l}2 \mathrm{~mL} \text { of acetic } \\
\text { anhydride/g of } \\
\text { protein, } 12\end{array}$ & $62.44 \%^{\mathrm{d}}$ & $49.52 \%$ & $\begin{array}{l}0.4 \mathrm{~mL} \text { acetic } \\
\text { anhydride/g of } \\
\text { protein, } 10\end{array}$ & $32.59 \%{ }^{d}$ & $45.09 \%{ }^{f}$ & $\begin{array}{c}1 \mathrm{~mL} \text { of acetic } \\
\text { anhydride/g of } \\
\text { protein and a pH } \\
\text { of } 12 .\end{array}$ & $9.39 \%{ }^{d}$ & $15.79 \%$ & [29] \\
\hline Mung bean & Succinylation & $\begin{array}{c}0.03 \text { succinic } \\
\text { anhydride: protein } \\
\text { weight ratio, } 9\end{array}$ & $91.64 \%$ & $100.72 \%$ & $\begin{array}{l}0.1 \text { succinic anhydride: } \\
\text { Protein weight ratio }\end{array}$ & $24.62 \mathrm{~m}^{2} / \mathrm{g}$ & $34.05 \mathrm{~m}^{2} / \mathrm{g}$ & & $\mathrm{N} / \mathrm{A}$ & & {$[30]$} \\
\hline
\end{tabular}


Table 1. Cont.

\begin{tabular}{|c|c|c|c|c|c|c|c|c|c|c|c|}
\hline $\begin{array}{l}\text { Protein } \\
\text { Source }\end{array}$ & Reaction & $\begin{array}{l}\text { Optimal Conditions } \\
\text { for Enhanced } \\
\text { Solubility } \\
\text { (\% of Modification } \\
\text { or Amount of } \\
\text { Chemical Agent, } \\
\text { Enzyme IA,pH) }\end{array}$ & \multicolumn{2}{|c|}{ Solubility ${ }^{a}$} & $\begin{array}{l}\text { Optimal Conditions } \\
\text { for Enhanced } \\
\text { Emulsifying Activity } \\
\text { (\% of Modification or } \\
\text { Amount of Chemical } \\
\text { Agent, Enzyme IA, } \\
\text { pH) }\end{array}$ & \multicolumn{2}{|c|}{ Emulsifying Activity ${ }^{a}$} & $\begin{array}{c}\text { Optimal } \\
\text { Conditions for } \\
\text { Enhanced Foam } \\
\text { Capacity } \\
\text { (\% of } \\
\text { Modification, } \\
\text { pH, and } \\
\text { Enzyme IA) }\end{array}$ & \multicolumn{2}{|c|}{ Foam Capacity ${ }^{a}$} & Ref. \\
\hline Brazil nut & Succinylation & $\begin{array}{l}0.5 \mathrm{~g} \text { of succinic } \\
\text { anhydride/g of } \\
\text { protein, } 12\end{array}$ & $87.17 \%^{\mathrm{d}}$ & $98.03 \%$ & $72 \%, 9$ & $\begin{array}{l}94.48 \mathrm{~mL} \\
\text { oil/100 mg of } \\
\text { protein h }\end{array}$ & $\begin{array}{l}112.42 \mathrm{~mL} \\
\text { oil/100 mg of } \\
\text { protein }\end{array}$ & & N/A & & [31] \\
\hline \multirow{2}{*}{ Pea } & \multirow{2}{*}{$\begin{array}{l}\text { Enzymatic } \\
\text { hydrolysis }\end{array}$} & Esperase, 7 & $51.05 \% \mathrm{~g}$ & $78.09 \%$ & Chymotripsin & $465.93 \mathrm{~mL} / \mathrm{g}$ & $742.7 \mathrm{~mL} / \mathrm{g}$ & Trypsin & N/A & 2271 & [32] \\
\hline & & Papain, 3 & $86.82 \% \mathrm{~g}$ & $98.53 \%$ & Commercial protease, 7 & $41.47 \mathrm{~m}^{2} / \mathrm{g}$ & $207.69 \mathrm{~m}^{2} / \mathrm{g}^{\mathrm{f}}$ & Papain, 7 & $348.48 \%{ }^{h}$ & $430.3 \% \mathrm{~g}$ & [33] \\
\hline Lupin & $\begin{array}{l}\text { Enzymatic } \\
\text { hydrolysis }\end{array}$ & Protamex, 8 & $80.7 \%^{\mathrm{i}}$ & $89.9 \%$ & Protease N-01 & $620 \mathrm{~mL} / \mathrm{g}$ & $679 \mathrm{~mL} / \mathrm{g}$ & Pepsin & $980 \%$ & $3614 \%$ & [34] \\
\hline Rapeseed & $\begin{array}{l}\text { Enzymatic } \\
\text { hydrolysis }\end{array}$ & $\begin{array}{l}15 \% \text {, alcalase } 2.4 \mathrm{~L}, \\
4.5\end{array}$ & $10 \%{ }^{j}$ & $79 \%$ & $10 \%$ & $18 \%$ & $49 \%$ & $5 \%$ & $44 \%$ & $63 \%$ & [35] \\
\hline Chickpea & $\begin{array}{l}\text { Enzymatic } \\
\text { hydrolysis }\end{array}$ & $14.67 \%, 12$ & $89.98 \%{ }^{d}$ & $98.44 \%$ & $4 \%$ & $273.74 \mathrm{~m}^{2} / \mathrm{g}$ & $309.86 \mathrm{~m}^{2} / \mathrm{g}$ & & N/A & & [36] \\
\hline Sesame cake & $\begin{array}{l}\text { Enzymatic } \\
\text { hydrolysis }\end{array}$ & $\begin{array}{l}26.3 \% \text { alcalase } \\
8.5\end{array}$ & N/A & $82.1 \%$ & $26.3 \%$ & $112.5 \mathrm{~m}^{2} / \mathrm{g}$ & $204.6 \mathrm{~m}^{2} / \mathrm{g}$ & $26.3 \%$ & $45.2 \%$ & $140.2 \%$ & [37] \\
\hline Chickpea & $\begin{array}{l}\text { Enzymatic } \\
\text { hydrolysis }\end{array}$ & $4.9 \%, 7$ & $64.49 \% \mathrm{~g}$ & $100.24 \%$ & $2.9 \%$ & $44.7 \%$ & $54 \%$ & $2.9 \%$ & $2.28 \%$ & $158.18 \%$ & [38] \\
\hline Peanut & $\begin{array}{l}\text { Enzymatic } \\
\text { hydrolysis }\end{array}$ & & N/A & & $5 \%$, flavourzyme & $44.92 \%$ & $47.84 \%$ & $5 \%$, flavourzyme & $32.15 \%$ & $165.12 \%$ & [39] \\
\hline $\begin{array}{l}\text { Black cumin } \\
\text { seeds }\end{array}$ & $\begin{array}{l}\text { Enzymatic } \\
\text { hydrolysis }\end{array}$ & Savinase, 10 & $85.87 \%$ & $91.32 \%$ & $12.58 \%$ & $155.5 \mathrm{~m}^{2} / \mathrm{g}$ & $189.5 \mathrm{~m}^{2} / \mathrm{g}$ & $12.58 \%$ & $81.9 \%$ & $90.5 \%$ & [40] \\
\hline Potato & $\begin{array}{l}\text { Enzymatic } \\
\text { hydrolysis }\end{array}$ & N/A & & $2 \%$ & & $359.75 \mathrm{~g} \mathrm{o}$ & g protein & $\begin{array}{c}416.84 \mathrm{~g} \text { oil } / \mathrm{g} \\
\text { protein }\end{array}$ & $\mathrm{N}$ & /A & [41] \\
\hline Soy & $\begin{array}{l}\text { Enzymatic } \\
\text { hydrolysis }\end{array}$ & $4 \%$, bromelain, 7 & $13.2 \%$ & $60.11 \%$ & & & $\mathrm{~N} / \mathrm{A}$ & & & & [42] \\
\hline Velvet bean & $\begin{array}{l}\text { Enzymatic } \\
\text { hydrolysis }\end{array}$ & Pancreatin, 10 & N/A & $75.8 \%$ & Pancreatin, 10 & N/A & 0.49 & Pancreatin, 10 & $\mathrm{~N} / \mathrm{A}$ & $110 \%$ & [43] \\
\hline $\begin{array}{l}\text { Camellia oleifera } \\
\text { seed cake }\end{array}$ & $\begin{array}{l}\text { Enzymatic } \\
\text { hydrolysis }\end{array}$ & Trypsin, 9 & $96.68 \%{ }^{j}$ & $96.68 \%$ & Alcalase,7 & $185.15 \mathrm{~m}^{2} / \mathrm{g}$ & $109.81 \mathrm{~m}^{2} / \mathrm{g}$ & Trypsin, 7 & $185.14 \%$ & $109.81 \%$ & [44] \\
\hline
\end{tabular}


Table 1. Cont.

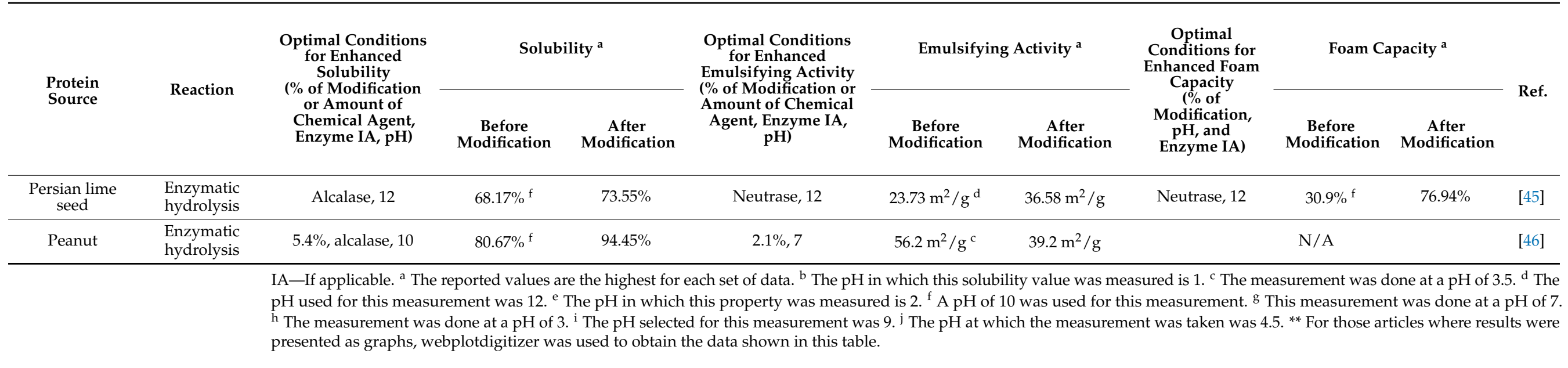




\subsection{Solubility}

Solubility is a property used to measure the degree to which one compound gets dissolved into another; protein solubility refers to how much protein gets dissolved into a solution $[24,47]$. Plant-based proteins need to be water-soluble to be incorporated into commercial applications for foods (specifically gels, foams, and emulsions), so it is quite common to determine this property first when exploring a new kind of protein $[47,48]$. When acetylation takes place, acetyl groups are covalently incorporated into the amino group of the protein, which results in a certain degree of protein unfolding (electrostatic attraction is diminished) [23]. Hydrophilic groups can be exposed, and therefore hydrophilicity increases, which improves solubility [21]. This will benefit other functional properties of the protein as well. Hydrogen bonds play a fundamental role in regulating protein and water interactions, and rely on electronegativity [49]. Thus, if the modified protein is more electronegative, it can interact with the media and form more hydrogen bonds, which increases solubility. Another factor to consider is the isoelectric point (pI), the $\mathrm{pH}$ where the net charge equals zero; the solubility is at its minimum here because the hydrophobic interactions between the protein molecules are greater than the electrostatic interactions between the protein and water molecules [50].

All these reasons explain what can be observed in Table 1, where the solubility values of all acetylated protein samples showed improvement compared to the native ones. Gruener and Ismond [20] reported that the solubility of a canola protein, with $26 \%$ acetylation, increased by nearly $12 \%$. Mung bean acetylation has also been reported to be beneficial in enhancing solubility values, El-Adawy [21] reported a significant improvement $(p \leq 0.05)$ in the solubility when compared to the native sample, and as seen in Table 1, it proved to be $23 \%$ higher than its unmodified counterpart. There was an increase of $4.21 \%$ in the solubility of the mucuna bean acetylated sample compared to the native sample [27]. The cowpea acetylated sample was nearly $52 \%$ higher than the native sample [28]. Since the isoelectric point is where solubility is at its minimum, it makes sense that these authors reported an increase in this functional property at higher $\mathrm{pH}$ values. The acetylated pumpkin protein sample was the only exception in enhancement, and it decreased by $12.92 \%$ compared to its unmodified counterpart [29]. The authors attributed this to an increase in the degradation of the protein present in the sample and more interactions among water and protein molecules, which resulted in fewer interactions between protein molecules and a lower solubility [47]. Concerning solubility, almost all authors reported an increase in this functionality, which was attributed to protein unfolding, which promotes the exposure of hydrophilic groups capable of establishing interactions with the solvent $[20-23,25,27-29]$. Thus, there is an enhancement in this functional property [20-23,25,27-29].

Despite these results with acetylated samples, succinylation has been reported as being more effective in changing protein conformations and functional properties because, by eliminating the positive charges of lysine, the negative charges increase [25]. This phenomenon directly affects the repulsive electrostatic forces, causing more unfolding from the native form. This change reduces interactions between protein molecules as water molecules can establish interactions with the unfolded protein, increasing the solubility [23,25,51]. As observed in Table 1, Gruener and Ismond [20] reported that the solubility for a succinylated sample was $16.56 \%$ higher than the native protein alternative, observing a slightly higher solubility for the succinylated sample than the acetylated one [20]. Mung bean protein modification has also been explored; the solubility of the succinylated sample improved by up to $23 \%$ (Table 1) [21,30], and, in the case of mucuna bean, although the solubility of the native protein was already higher than $90 \%$, the succinylation increased this trait by $9.08 \%$ [27]. Succinylation also improved the solubility of the Bambara groundnut protein (Table 1) by $3.08 \%$ in the succinylated sample compared to its unmodified counterpart [25]. The sample Brazil nut modified with succinylation was nearly $13 \%$ greater than its unmodified part [31]. The modification of the cowpea protein sample by succinylation increased its solubility by nearly $47 \%$ [28]. In summary, solubility 
enhancement through succinylation results from an increase in short-range repulsive forces, reducing the protein-protein interaction, thus increasing this functional property [25].

Modification via hydrolysis lowers the average molecular weight and frees ionizable groups, resulting in a better solubility [18]. As shown in Table 1, the solubility of the modified pea protein sample increased by $59.40 \%$ compared to its native counterpart [32]. Other authors also reported improved solubility for hydrolyzed pea protein samples compared to unmodified counterparts [33]. The solubility of the lupin hydrolyzed sample proved to be $9.20 \%$ higher than the native form [34]. There was an increase of $31 \%$ in rapeseed protein hydrolysate compared to a native sample [35]. Despite the interesting results from different authors, existing information about the impact of enzymatic hydrolysis on the taste or flavor of produced proteins is limited.

In comparison to the native pea protein isolate, it was found that the bitter flavor increased in pea protein hydrolysates produced with savinase and alcalase, $15 \mathrm{~min}$ after the reaction takes place (from 3 to 6.7 and 6.5, respectively); the bitterness was reduced (to 6.5 and 5.4, respectively) by increasing the reaction time to $120 \mathrm{~min}$ [32]. Furthermore, sensory analysis of alcalase $2.4 \mathrm{~L}$ hydrolysates was performed, and it was evaluated as highly bitter (7.2) [34]. Hence, taste and flavor after hydrolysis should be considered as peptides can have a bitter taste compared with original proteins [52].

If proteins are in a low or high $\mathrm{pH}$ region, their charges can be either net positive or net negative, respectively, creating a repulsive electrostatic force that keeps protein molecules separated. As a result, the native form (which is folded) starts to unfold, and the equilibrium shifts to the unfolded form, which reveals the hidden functional groups present in the protein molecules [53,54]. As a result, there are more places for possible interactions between protein and solvent; intramolecular interactions, such as hydrogen bonds, can occur, and therefore solubility increases [54]. Among the modifications mentioned above, succinylation enhanced solubility (compared to its unmodified counterparts) because it favored protein unfolding, which contributes to establishing more interactions with the solvent.

\subsection{Emulsifying Capacity}

Emulsifying capacity is a term used to describe the ability of a compound to create emulsions, which consist of two liquids with different solubilities, where one creates small drops that get suspended in the other before a phase inversion occurs [24,55]. Proteins can form a film that surrounds the oil droplets present in a medium, and, by doing this, they avoid changes like creaming, coalescence, sedimentation, or flocculation [56]. The factors that affect the emulsifying capacity are the type of protein, the concentration at which this protein is present, and the $\mathrm{pH}$ [57].

The higher values observed in the emulsifying activity of the acetylated samples are probably caused by the improvement in solubility (Table 1) [20]. While in the interface, composed of oil and water, and to reduce surface tension, the protein aligns the hydrophobic residues towards the oil phase and the lipophobic residues towards the aqueous phase. Therefore, acetylation promotes the reveal of hydrophobic and lipophobic residues, which results in better emulsifying properties [27]. As observed in Table 1, the emulsifying capacity of an acetylated canola protein sample improved by $35.80 \%$ compared to its native counterpart [20]. The modification of mucuna bean protein using acetylation also increased the emulsifying capacity by $3.26 \%$ (Table 1 ) [27].

With the succinylation process, carboxyl groups can be added, thus promoting interactions among the aqueous phase of emulsions and the protein [21]. Therefore, if a protein is soluble, its emulsifying capacity will be directly affected [31]. Another factor that explains the enhancement of this property in the succinylated protein samples is molecular flexibility, which allows a protein to rearrange more easily in the interface [20]. This was observed by Gruener and Ismond [20], who reported that the emulsifying capacity of succinylated canola protein sample was enhanced by $60.20 \%$ (Table 1) [20]. The modification of mucuna bean protein through succinylation was also reported to improve the emulsifying 
capacity, increasing by $5.29 \%$ for its modified counterpart (Table 1) [28]. The succinylation of Bambara groundnut protein was also beneficial for its emulsifying activity, increasing the functionality by $3.37 \%$ for its modified counterpart (Table 1) [25]. The emulsifying capacity of the succinylated Brazil nut protein sample proved to be nearly $20 \%$ greater than its unmodified counterpart [31].

The surface hydrophobicity of emulsions is enhanced through enzymatic hydrolysis by making the hydrophobic groups more available for interaction, which, as a result, promotes film formation that can surround the oil droplets; thus, emulsifying properties improve [18,58]. For example, Mokni et al. [36] reported an emulsifying capacity that was $88 \%$ higher in the hydrolyzed samples (Table 1) [36]. Enhancement by enzymatic hydrolysis was attributed to the solubility and flexibility of the molecules [36]. As seen in Table 1, succinylated sesame protein also showed a higher emulsifying capacity, going from $112.5 \mathrm{~m}^{2} / \mathrm{g}$ for the native sample to $176.5 \mathrm{~m}^{2} / \mathrm{g}$ for the succinylated counterpart [37]. As in the case of sesame protein, rapeseed also improved its emulsifying capacity by $31 \%$ [35]. We can conclude from the modifications mentioned above that succinylation is the best method to enhance emulsifying properties, since this modification allows protein molecules to have more flexibility. Therefore, they can rearrange in the oil-water interface [20].

\subsection{Foaming Capacity}

Foaming capacity is used to describe the ability of a compound to form foams, which are composed of a gas (in the form of small bubbles) dispersed in a solid or a liquid and are formed by a whipping process [24]. By incorporating bubbles in a food system, the density of a food product can be diminished and therefore lower-calorie food applications can be created [59]. For this reason, several authors have made efforts to research the foaming capacity of plant-based proteins (Table 1). Among (but not limited to) the protein sources that have been studied are canola, chickpea, mung bean, lentil, Bambara groundnuts, and Brazil nuts [20-22,25,30,36,38,39].

Acetylation has been effective in improving foaming capacity. This reaction introduces acetyl groups for the $\varepsilon$ amino groups, lowering the number of positive charges [21]. In addition, the molecular size of acetylated samples is diminished, which allows them to have faster movement toward the air-water interface [20]. These contribute to the increase in foaming capacity, explaining what is shown in Table 1, where chemically modified protein samples had higher values than their unmodified counterparts. For instance, the acetylated canola protein sample proved to be $146.4 \%$ higher than the native sample, in terms of foaming capacity [20], whereas the acetylated mung bean protein sample also showed a higher capacity (24.98\%) compared to its untreated form [21]. Furthermore, a slight improvement (by $2 \mathrm{~mL}$ ) in the foaming capacity of the acetylated lentil protein sample was also observed [22]. Therefore, it is concluded that acetylation has a positive effect on the enhancement of foaming capacity, by lowering the molecular size and replacing hydrophobic acetyl groups (which decreases the number of positive charges), which result in a facilitated movement into the air-water interface $[20,21]$.

Succinylation causes an increase in the hydrophilic acyl groups, the charge is negative, and it stimulates interactions of protein and water molecules [21,27]. This is consistent with the values observed in Table 1, where the succinylated sample of canola protein was $114.7 \%$ higher than that of the native form [20]. El-Adawy [21] also reported an improvement $(19.15 \%)$ in the foaming capacity compared to its untreated form. Cowpea protein isolates showed an enhancement of close to 51\% when succinylated [28]. In conclusion, succinylation improves foaming capacity since this modification increases the number of hydrophilic groups, facilitating interactions between protein and water molecules [21,27].

On the other hand, hydrolysis proved to be beneficial for almost all the proteins in terms of foaming capacity. For example, chickpea protein hydrolysate showed a remarkable improvement, close to $156 \%$ (Table 1), after modification [38]. The improvement in the foaming capacity of pea protein was also observed, where this value was $81.81 \%$ greater for pea hydrolysates [33]. Lupin protein hydrolysates showed a remarkable enhancement 
of $2634 \%$ compared to their untreated form [34]. Hydrolysis also proved to benefit the foaming capacity of peanut protein, with an increase of almost $133 \%$ in the value of the hydrolysate [39]. When the hydrolysis process takes place, there are changes in the size of the peptides in the hydrolysate and the surface hydrophobicity, and therefore this property is enhanced [32]. This goes hand in hand with the findings presented by other authors, who indicated that peptides generated during the hydrolysis process possess a lower molecular weight, which also gives them more flexibility to move towards the air-water interface when bubbles are formed [40]. Without a doubt, hydrolysis was the best way to improve the foaming capacity because the surface hydrophobicity was diminished, and the peptides have more flexibility to move towards the air-water interface, which contributes to an enhancement in this property $[32,40]$.

\subsection{Protein Digestibility and Amino Acid Profile}

Digestibility is a term used to describe the amount of protein ingested by an organism in proportion to the consumed amount, and it depends on factors like the structure of the protein, pre-processing, and if compounds that can restrict digestion are present (antinutritional factors) [60]. Tannins are antinutritional factors capable of causing proteins to precipitate [61]. They are present in millet, sorghum, and pulses and bind to digestive enzymes, starch, and proteins [62]. This entails a reduced nutritional value in foods that contain them [62]. Both acetylation and succinylation contributed to a significant increase $(p \leq 0.05)$ in digestibility [21]; and this change was attributed to the destruction of antinutritional factors through chemical modifications [21]. Humans need to consume 20 amino acids, of which 11 are non-essential, and the remaining nine are essential because they must be acquired through diet [63]. Among this classification, the following amino acids are included: tryptophan, histidine, methionine, leucine, isoleucine, threonine, valine, phenylalanine, and lysine [64]. To determine if modification by enzymatic hydrolysis had a beneficial effect on the nutritional value, the amino acid compositions of chickpea protein hydrolysates were obtained. Authors found no significant variances compared to their unmodified counterparts [38]. In contrast, other authors did find an effect on the nutritional value of chickpea hydrolysates (the protein content increased) [36]. These authors attributed this change to the proteolytic cleavage of peptide bonds, which causes a decrease in the number of insoluble proteins and increases the soluble kind [36]. We discovered that not all authors evaluated digestibility $[20,22,27,28,30-33,35,37,39,40,42-46]$ and amino acid profiles of the chemically modified proteins were only determined by a few authors $[36,44,45]$. This represents an opportunity when studying plant-based proteins for food applications.

The quality of a protein refers to its capacity to fulfill the metabolic needs of the human body, and is thus related to the amino acid concentration in the food, its profile, and its digestibility [65]. The protein quality is then measured by considering its bioavailability and functionality; these factors also include health benefits and digestibility [26]. A method that can be used for the determination of the quality of a protein is called the protein efficiency ratio (PER), which measures the amount of weight that rats gain after 28 days of consuming a protein and compares it to the weight gain of casein consumption (which is a protein of good quality) [66].

However, the protein digestibility-corrected amino acid score (PDCAAS) and digestible indispensable amino acid score (DIAAS) are the two main protocols used to qualify how good a protein is for human consumption [67]. PDCAAS is employed to determine the quality of a protein when consumed as food by considering the essential amino acids profile as an indispensable amino acid score and the digestibility of the protein [2]; however, this procedure has the disadvantage of calculations taking into account the digestibility of crude protein in the whole tract and considers that all amino acids possess similar digestibility to crude protein [68]. In order to fix this limitation, a new standard to determine protein quality, DIAAS, was created [15]. DIAAS considers the digestibility of the amino 
acids in the ileum; therefore, the true digestibility of amino acids in a certain food can be obtained [66].

Considering all these factors, the determination of DIASS and PDCAAS was found to be absent in the works that were reviewed. Since modified proteins are novel foods (whose digestibility and amino acid compositions are uncertain), an assessment of their digestibility and amino acid score should be prioritized. Then, it can be determined if these modified proteins would provide a good nutritional value when humans consume them. If applicable, some of these novel foods could be incorporated into diets.

\section{Patents, Ingredients, and Regulations Based on Modified Plant-Based Proteins}

\subsection{Patents}

Patents refer to exclusive rights stipulated for an invention that can be a process or a product that confers a novel way to make something for a limited period of protection (usually up to 20 years) to its holder [69]. In this time, no one can replicate what the invention stipulates without the holder's permission [69]. As expected, modified plantbased proteins have been subject to registration as inventions. In Table 2, some of these inventions are listed.

Table 2. Patents associated with the production of plant-based proteins.

\begin{tabular}{|c|c|c|c|c|}
\hline $\begin{array}{c}\text { Patent } \\
\text { Number/Country of } \\
\text { Application }\end{array}$ & Patent Name & $\begin{array}{c}\text { Type of } \\
\text { Modification }\end{array}$ & Description of the Invention & Reference \\
\hline ES2535985T3/Spain & $\begin{array}{l}\text { Vegetable protein } \\
\text { hydrolysis }\end{array}$ & Hydrolysis & $\begin{array}{l}\text { Sunflower protein is mixed with another } \\
\text { vegetable protein (although more can be } \\
\text { used), which can be rapeseed protein, corn } \\
\text { protein or both; this is then subjected to } \\
\text { hydrolysis (which can be done through the } \\
\text { enzymatic approach, with proteases or } \\
\text { through the non-enzymatic route with the aid } \\
\text { of an acid). The modified protein can improve } \\
\text { organoleptic properties and thus can be used } \\
\text { in food products like soups, meats, } \\
\text { and sauces. }\end{array}$ & [70] \\
\hline CN104754955B/China & $\begin{array}{l}\text { The mild hydrolysis } \\
\text { of protein from rice } \\
\text { bran }\end{array}$ & Hydrolysis & $\begin{array}{l}\text { Protease and a rice bran suspension are used } \\
\text { to create a rice hydrolysate, with a desired } \\
\text { degree of hydrolysis of } 10-16 \% \text {, the protein } \\
\text { content of } 30-45 \% \text { in dry matter, } 40-60 \% \\
\text { carbohydrate, and finally } 0-5 \% \text { of fat. }\end{array}$ & [71] \\
\hline $\begin{array}{l}\text { WO 2011/107311 } \\
\text { A1/Worldwide }\end{array}$ & $\begin{array}{c}\text { Hygienic product } \\
\text { with antimicrobic and } \\
\text { antifungal properties }\end{array}$ & Hydrolysis & $\begin{array}{l}\text { Hydrolyzed plant-based protein (which can } \\
\text { be a hydrolyzed soy protein with silanol } \\
\text { groups or hydrolyzed wheat protein that has } \\
\text { polyvinylpyrrolidone attached to its lateral } \\
\text { amino groups or its ends) is used as a } \\
\text { copolymer in fibers of hygiene products, so } \\
\text { they become more hydrophilic and have } \\
\text { less tangling. }\end{array}$ & {$[72]$} \\
\hline $\begin{array}{l}\text { WO } 2020 / 251467 \\
\text { A1/Worldwide }\end{array}$ & $\begin{array}{l}\text { Method of preparing } \\
\text { plant protein based } \\
\text { absorbent material } \\
\text { and absorbent } \\
\text { material thus } \\
\text { produced }\end{array}$ & Acylation & $\begin{array}{l}\text { A liquid and a plant-based protein (generated } \\
\text { as a product by the industry, an example } \\
\text { being potato protein obtained from starch) are } \\
\text { used to create a suspension (this kind of } \\
\text { protein is insoluble in the media), an } \\
\text { acylating agent is then added (the suggested } \\
\text { compound is ethylenediaminetetraacetic } \\
\text { dianhydride, but succinic anhydride can be } \\
\text { used as well) to modify the protein and a } \\
\text { plant-based absorbent material is obtained. }\end{array}$ & [73] \\
\hline
\end{tabular}


Table 2. Cont.

\begin{tabular}{|c|c|c|c|c|}
\hline $\begin{array}{c}\text { Patent } \\
\text { Number/Country of } \\
\text { Application }\end{array}$ & Patent Name & $\begin{array}{c}\text { Type of } \\
\text { Modification }\end{array}$ & Description of the Invention & Reference \\
\hline $\begin{array}{l}\text { WO 2018/125920 } \\
\text { A1/Worldwide }\end{array}$ & $\begin{array}{l}\text { Method of } \\
\text { manufacturing a } \\
\text { nutritional powder } \\
\text { with in situ protein } \\
\text { hydrolysis }\end{array}$ & Hydrolysis & $\begin{array}{l}\text { A source of protein (such as pea protein } \\
\text { isolate, sodium caseinate, oat protein isolate, } \\
\text { sunflower protein isolate, among others) } \\
\text { along with other ingredients is extruded to } \\
\text { form a slurry, which then is used to create an } \\
\text { emulsion (composed by } 5-35 \% \text { protein) and } \\
\text { hydrolyzed with the aid of a protease and } \\
\text { extrusion technology. Finally, the product (of } \\
\text { which the desired degree of hydrolysis ranges } \\
\text { between } 5-30 \% \text { ) is dried and milled to obtain } \\
\text { a nutritional powder. }\end{array}$ & {$[74]$} \\
\hline $\begin{array}{l}\text { EP0976331B1/ } \\
\text { European Union }\end{array}$ & $\begin{array}{l}\text { Soybean protein } \\
\text { hydrolysates, their } \\
\text { production and use }\end{array}$ & Hydrolysis & $\begin{array}{l}\text { 7S ( } \beta \text {-conglycinin) and 11S (glycinin) } \\
\text { fractions of soybean protein are used to create } \\
\text { polypeptide hydrolysates. Since these } \\
\text { products are capable of delaying aging or } \\
\text { retrogradation (specifically of starches), they } \\
\text { can be used as food additives in products that } \\
\text { contain them; these hydrolysates show } \\
\text { improved whipping and emulsifying } \\
\text { properties in acidic pH (compared with the } \\
\text { conventional polypeptides) in acidic pH and } \\
\text { therefore can be used as an ingredient in } \\
\text { mayonnaise, coffee whitener, dressing and } \\
\text { other products. }\end{array}$ & [75] \\
\hline CA3118136A1/Canada & $\begin{array}{c}\text { Corn protein } \\
\text { hydrolysates and } \\
\text { methods of making }\end{array}$ & Hydrolysis & $\begin{array}{l}\text { The corn protein is used to create a } \\
\text { suspension subjected to hydrolysis by an } \\
\text { enzyme at a ratio of 1:100 (weight of enzyme } \\
\text { to corn protein). Therefore, the product } \\
\text { should at least have a degree of hydrolysis of } \\
1-17 \% \text { and a minimum corn protein content } \\
\text { in weight of } 75 \% \text {. This product can be used } \\
\text { alone or with other proteins in } \\
\text { beverage applications. }\end{array}$ & [76] \\
\hline $\begin{array}{l}\text { EP } 2384124 \text { B1/ } \\
\text { European Union }\end{array}$ & $\begin{array}{l}\text { Protein hydrolysate } \\
\text { compositions }\end{array}$ & Hydrolysis & $\begin{array}{l}\text { A source of protein (some examples include } \\
\text { soy, lupin, sunflower, and soy) and an } \\
\text { endopeptidase are used to create a } \\
\text { hydrolysate composed of various } \\
\text { polypeptides enriched in a } 47 \mathrm{kDa} \text { fragment. }\end{array}$ & [77] \\
\hline CN104336619A/China & $\begin{array}{l}\text { Protein system and } \\
\text { food products } \\
\text { including same }\end{array}$ & Hydrolysis & $\begin{array}{l}\text { This patent describes the procedure to } \\
\text { prepare a mixture of partially hydrolyzed } \\
\text { dairy protein and partially hydrolyzed } \\
\text { legume protein to increase the shelf-life of } \\
\text { the system. }\end{array}$ & [78] \\
\hline $\begin{array}{l}\text { US 2006/0228463 } \\
\text { A1/United States }\end{array}$ & $\begin{array}{c}\text { Soy protein isolate } \\
\text { composition having } \\
\text { improved } \\
\text { functionality }\end{array}$ & Chemical & $\begin{array}{l}\text { A soy protein isolate is prepared, an acid is } \\
\text { then added to precipitate the protein, which is } \\
\text { then hydrated, and then a base is used to } \\
\text { obtain a neutral soy protein curd suspension. } \\
\text { This product is then modified with an agent } \\
\text { of choice (sodium hypochlorite, } \\
\text { transglutaminase, a fatty acid, among others) } \\
\text { to improve its functional properties. }\end{array}$ & [79] \\
\hline
\end{tabular}


Table 2. Cont.

\begin{tabular}{|c|c|c|c|c|}
\hline $\begin{array}{c}\text { Patent } \\
\text { Number/Country of } \\
\text { Application }\end{array}$ & Patent Name & $\begin{array}{c}\text { Type of } \\
\text { Modification }\end{array}$ & Description of the Invention & Reference \\
\hline $\begin{array}{l}\text { US 3,764,711/ } \\
\text { United States }\end{array}$ & $\begin{array}{l}\text { Acylated protein for } \\
\text { coffee whitener } \\
\text { formulations }\end{array}$ & Acylation & $\begin{array}{l}\text { A protein (that can come from plants or } \\
\text { animals) is dispersed in water and an alkaline } \\
\text { medium (such as sodium carbonate or } \\
\text { sodium hydroxide), this agent can acylate } \\
\text { electro-negative groups present (which can be } \\
\text { oxygen, nitrogen, or sulfur) in the chosen } \\
\text { protein; modified protein can be isolated from } \\
\text { the medium, or it can be maintained in it for } \\
\text { its incorporation in coffee or tea } \\
\text { whitener formulation. }\end{array}$ & [80] \\
\hline
\end{tabular}

\begin{tabular}{|c|c|c|c|c|}
\hline $\begin{array}{l}\text { EP0495391A1/ } \\
\text { European Union }\end{array}$ & $\begin{array}{l}\text { A process for the } \\
\text { production of } \\
\text { hydrolyzed vegetable } \\
\text { proteins using } \\
\text { gaseous hydrochloric } \\
\text { acid } \\
\text { and the product } \\
\text { therefrom }\end{array}$ & Hydrolysis & $\begin{array}{l}\text { A vegetable protein (which can belong to the } \\
\text { oil-seeds proteins, grain proteins or leaf } \\
\text { proteins) is added to an aqueous solution } \\
\text { (which contains a minimum of } 1 \text { protease) } \\
\text { and hydrolyzed at a temperature range of } \\
25-75^{\circ} \mathrm{C} \text { and a pH range of } 5.5-8.5 \text { (the exact } \\
\text { reaction conditions depend on the protein } \\
\text { and enzymes chosen). }\end{array}$ & [81] \\
\hline $\begin{array}{l}\text { US20050025877A1/ } \\
\text { United States }\end{array}$ & $\begin{array}{c}\text { Hydrolyzed } \\
\text { vegetable protein } \\
\text { liquid compositions }\end{array}$ & Hydrolysis & $\begin{array}{l}\text { A vegetable source of protein (preferably } \\
\text { soybean, although wheat, corn, rice, or other } \\
\text { vegetable sources of protein can be used) is } \\
\text { hydrolyzed using sulfuric acid as } \\
\text { liquid seasoning. }\end{array}$ & [82] \\
\hline $\begin{array}{c}\text { US 6,251,443 B1/ } \\
\text { United States }\end{array}$ & $\begin{array}{l}\text { Method for } \\
\text { producing a savory } \\
\text { flavor base }\end{array}$ & Hydrolysis & $\begin{array}{l}\text { Cereal grain protein (defatted wheat germ is } \\
\text { preferred) and water to create a slurry, then } \\
\text { pasteurized and cooled. After that, an } \\
\text { enzyme is added to hydrolyze the mixture } \\
\text { and the pH is lowered; insoluble materials are } \\
\text { separated from the combination, and the } \\
\text { savory flavor base is obtained. }\end{array}$ & [83] \\
\hline CN113163782A/China & $\begin{array}{l}\text { Non-dairy analogs } \\
\text { with succinylated } \\
\text { plant proteins and } \\
\text { methods of using } \\
\text { such products }\end{array}$ & Succinylation & $\begin{array}{l}\text { A plant protein (which must contain at least a } \\
\text { minimum amount of a succinylated protein), } \\
\text { a minimum of one lipid, one emulsifier, and } \\
\text { water at a pH range of } 4-10 \text { is used to } \\
\text { generate a dairy-free product. The } \\
\text { succinylated protein, along with water or } \\
\text { carbonated water and at a pH range of } 4-9, \\
\text { can also be used to produce beverages. }\end{array}$ & [84] \\
\hline $\begin{array}{l}\text { EP } 2468109 \text { A1/ } \\
\text { European Union }\end{array}$ & $\begin{array}{l}\text { Plant protein } \\
\text { hydrolysates }\end{array}$ & Hydrolysis & $\begin{array}{l}\text { This is a membrane reactor capable of } \\
\text { hydrolyzing plant-based proteins on a } \\
\text { temperature range of } 25-75^{\circ} \mathrm{C} \text { and } \\
\text { continuous stirring, allowing large-scale } \\
\text { hydrolysis. In addition, plant-based proteins } \\
\text { can be used to create suspensions, to which } \\
\text { an enzyme can be added so that it hydrolyses } \\
\text { the protein, this is then filtered, and a } \\
\text { plant-based protein hydrolysate for food } \\
\text { applications is obtained. }\end{array}$ & [85] \\
\hline CN108041254B/China & $\begin{array}{l}\text { Fishy smell-free } \\
\text { high-emulsibility } \\
\text { isolated soy protein } \\
\text { and preparation } \\
\text { method thereof }\end{array}$ & $\begin{array}{l}\text { Succinylation } \\
\text { and } \\
\text { fermentation }\end{array}$ & $\begin{array}{l}\text { Defatted soybean meal is succinylated with } \\
\text { succinic anhydride and fermented with lactic } \\
\text { acid bacteria (among other things) to obtain a } \\
\text { soybean protein isolate that lacks the fish-like } \\
\text { smell and possesses a high emulsibility. }\end{array}$ & [86] \\
\hline
\end{tabular}


Table 2. Cont.

\begin{tabular}{|c|c|c|c|c|}
\hline $\begin{array}{c}\text { Patent } \\
\text { Number/Country of } \\
\text { Application }\end{array}$ & Patent Name & $\begin{array}{c}\text { Type of } \\
\text { Modification }\end{array}$ & Description of the Invention & Reference \\
\hline CN102334588B/China & $\begin{array}{l}\text { Preparation method } \\
\text { for enzyme-modified } \\
\text { peanut protein }\end{array}$ & Hydrolysis & $\begin{array}{l}\text { Defatted peanut protein and distilled water } \\
\text { are used to prepare a suspension with the aid } \\
\text { of a microwave is dissolved. Then an alkali } \\
\text { extraction takes place, the mixture is then } \\
\text { centrifuged, and a protease is added, the } \\
\text { hydrolysis takes place in the microwave, and } \\
\text { finally, an enzyme-modified peanut protein } \\
\text { is generated. }\end{array}$ & [87] \\
\hline
\end{tabular}

Non-dairy creamers
comprising protein
hydrolysate
United States $\quad \begin{gathered}\text { compositions and } \\ \text { method for } \\ \text { producing the } \\ \text { non-dairy creamers }\end{gathered}$

A soy-based protein hydrolysate composed of protein and some polypeptide fragments (with a degree of hydrolysis of at least $0.2 \%$ ) is used as a dairy-free product.

An enzyme that has granular starch hydrolyzing activity (GSH) and a second enzyme able to hydrolyze starch is used to hydrolyze the starch present in a rice

\section{EP 2608682 B1/}

European Union

Method of making a snack bar comprising a low temperature rice protein concentrate
Hydrolysis substrate at a temperature of up to $72{ }^{\circ} \mathrm{C}$ and a $\mathrm{pH}$ range of 3-6, the reaction is performed until a solubilized starch part, and a residue fraction (that contains the insoluble rice protein) can be obtained. Next, the solubilized starch part is separated from the residue part for the obtention of a rice protein concentrate, which is then dispersed in a medium that allows the formation of wet dough to produce a snack bar.
A chymotrypsin-like serine protease enzyme is used to hydrolyze a legume protein isolate with a preferred degree of hydrolysis of $12 \%$ or less and the desired solubility superior to $80 \%$ at a $\mathrm{pH}$ of 5 for its usage in food or pharmaceutical applications.
WO 2020/109741

A1/Worldwide
Hydrolysis
A peptidase is used to hydrolyze cereal protein (wheat protein is preferred, although other sources can be used) at a temperature range of $55-75^{\circ} \mathrm{C}$ and the desired $\mathrm{pH}$ range of 5.5-6. The resulting product can replace milk protein, and it can also be used as an ingredient in beverages or flavor enhancer.

\section{US 9,259,018 B2 United Partially hydrolyzed States}

Hydrolysis 
Table 2. Cont.

\begin{tabular}{|c|c|c|c|c|}
\hline $\begin{array}{c}\text { Patent } \\
\text { Number/Country of } \\
\text { Application }\end{array}$ & Patent Name & $\begin{array}{c}\text { Type of } \\
\text { Modification }\end{array}$ & Description of the Invention & Reference \\
\hline $\begin{array}{l}\text { US 2013/0209611 A1 } \\
\text { United States }\end{array}$ & $\begin{array}{l}\text { Food protein } \\
\text { ingredient and } \\
\text { methods for } \\
\text { producing }\end{array}$ & Hydrolysis & $\begin{array}{l}\text { A raw material that contains keratin (such as } \\
\text { wool, hair, claws, nails, among others) or a } \\
\text { material that contains protein (which can } \\
\text { come from plants or animals) is pretreated so } \\
\text { that the protein denaturation takes place. } \\
\text { Then, a proteolytic enzyme (like an } \\
\text { endoprotease, protease, exoprotease or a } \\
\text { mixture of those) at a pH of } 6-8 \text { and a } \\
\text { temperature of } 55-80^{\circ} \mathrm{C} \text { is used to hydrolyze } \\
\text { the starting material (emulsifying while doing } \\
\text { so is preferred). Finally, the hydrolyzate is } \\
\text { processed to stabilize it on the shelf. } \\
\text { Desirably, the final product has stability at } \\
\text { room temperature, a digestibility of } 85-100 \% \\
\text { and good palatability. }\end{array}$ & [92] \\
\hline $\begin{array}{c}\text { US 9,693,576 B2 United } \\
\text { States }\end{array}$ & Fermented ingredient & $\begin{array}{l}\text { Hydrolysis and } \\
\text { fermentation }\end{array}$ & $\begin{array}{l}\text { Pea protein is hydrolyzed (either by acid or } \\
\text { by adding an enzyme with proteinase and } \\
\text { peptidase activity). Subsequently, this } \\
\text { hydrolysate is fermented using a Lactobacillus } \\
\text { species at an initial pH of at least six and left } \\
\text { at incubation until a final pH of at least } 5.5 \text { is } \\
\text { reached. The final product can be employed } \\
\text { as an ingredient that enhances the salty flavor. }\end{array}$ & [93] \\
\hline
\end{tabular}

From Table 2, it can be noted that most of the patents presented correspond to the modification of plant-based proteins via hydrolysis. For instance, the patent "Vegetable protein hydrolysis", which was registered in Spain, explores the utilization of sunflower protein (either alone or mixed with another vegetable protein, such as rapeseed protein, corn protein, or both) and its subsequent modification by hydrolysis for the improvement of organoleptic properties in food products [70]. Another patent that also mentions that sunflower protein hydrolysis is a "Method of manufacturing a nutritional powder with in situ protein hydrolysis", where it is described that the protein is extruded and then hydrolyzed to obtain a nutritional powder [74]. A Chinese patent titled "Protein system and food products including same" uses a mixture of partially hydrolyzed dairy protein and partially hydrolyzed legume protein to increase shelf life [78]. A Chinese patent is also a mild hydrolysis using protease and protein from rice bran to obtain a rice hydrolysate with a 30-45\% protein content [71]. Modification by hydrolysis of corn protein has also been explored in the Canadian patent "Corn protein hydrolysates and methods of making" to obtain a hydrolysate with a minimum corn protein content weight of $75 \%$ for its application in beverages [76]. In "A process for the production of hydrolyzed vegetable proteins using gaseous hydrochloric acid and the product therefrom", protein from either oil seeds (peanut, sunflower, cottonseed, or soy), grains, leaves, a combination of all or from other vegetal sources is subject to hydrolysis at a temperature range of $25-75^{\circ} \mathrm{C}$ and a $\mathrm{pH}$ range that goes from 5.5-8.5 to produce a hydrolysate with a minimum degree of solubility of $60 \%$ (although this level is preferred to be a minimum of $90 \%$ ) [81].

Acylation as a protein modification process has also been explored, for example, in the patent "Method of preparing plant protein-based absorbent material and absorbent material thus produced", where a plant-based protein (as an industrial byproduct, potato protein is suggested) is mixed with a liquid, an acylating agent of choice (which can be ethylenediaminetetraacetic dianhydride or succinic anhydride) is then added to obtain a modified plant-based protein that works as an absorbent material [73]. In the United States, this modification was also addressed in "Acylated protein for coffee whitener 
formulations", where a protein (either of animal or vegetal sources) is acylated, and the product can be incorporated in coffee or tea whitener formulations [80]. Succinylation of proteins has been explored as well, for instance, in "Non-dairy analogs with succinylated plant proteins and methods of using such products", a patent filled in China, a succinylated protein is mixed with additional ingredients to obtain a dairy-free product that can be incorporated in beverages too [84]. Another patent from China called "Fishy smell-free high-emulsibility isolated soy protein and preparation method thereof" talks about the modification of defatted soybean meal by succinylation and its subsequent fermentation with lactic acid to produce a soybean protein isolate without the fish-like smell [86]. To summarize, in most of the registered patents, hydrolysis modification was explored, and most of them modified the plant-based proteins for food applications.

Another factor of relevance regarding patents on plant-based protein processes is the popular soybean protein. Among the patents that mention protein from this oilseed as a raw material are WO 2011/107311 A1 and EP 0976331 B1: “Hygienic product with antimicrobic and antifungal properties" and "Soybean protein hydrolysates, their production and use", respectively. In the first one, the soybean protein is modified by hydrolysis and an attachment of silanol groups and applies as a copolymer in fibers of hygiene products [72]. In the second patent: "Soybean protein hydrolysates, their production and use," inventors use two fractions of soy protein (7S and 11S) to obtain polypeptide hydrolysates that can be beneficial for the food industry delaying starch retrogradation and improving whipping and emulsifying characteristics in acidic $\mathrm{pH}$ [75]. Both soy protein and the modification by hydrolysis by using an endopeptidase were used in the patent: "Protein hydrolysate compositions" (the patent mentions other vegetal protein sources as well) to obtain a hydrolysate that contains some polypeptides enriched in a $47 \mathrm{kDa}$ fragment [77].

Following the examples of patents using soybean proteins, one of them being interesting because of the usage of additional agents to proteases is: "Soy protein isolate composition having improved functionality". In this patent, inventors registered the modification of soy protein with the desired agent (sodium hypochlorite, transglutaminase, a fatty acid, among others) to obtain a soy protein isolate with improved functional properties [79]. Furthermore, the patent "Hydrolyzed vegetable protein liquid compositions" mentions the preference of soy protein (although nuts, wheat, nuts, corn, and their mixtures can also be used) for its hydrolysis by sulfuric acid to obtain a hydrolyzed vegetable liquid seasoning [82]. To conclude, hydrolysis may be preferred, as seen in the list of main patents reported (Table 2), over other types of modifications (such as acetylation and succinylation) because it lowers the average molecular mass of protein and frees ionizable groups. Furthermore, these aspects enhance protein solubility, foaming, and emulsifying capacity, being an effective way to improve poor functional properties in the industry [18].

One of the reasons behind the majority of the patents being associated with soy protein rather than with other plant-based protein sources is, indeed, economic interest, with four major trading companies associated worldwide with this oilseed: Daniels Midland (ADM), Bunge, Cargill, and Louis Dreyfus, the four of them also being in control of almost all the global trading and price control of the grains [94], but also it is important to consider the nutritional importance of this seed complying with all of the amino acids required in human nutrition [95]. With the patents described in Table 2, it can be seen that if a cereal or grain-derived protein has poor functional properties (such as solubility, emulsifying capacity, and foaming capacity), it will not be useful for food applications or industry. Therefore, research and development into techniques to enhance these properties must be performed. In summary, soy protein is the most explored plant-based source for modification because of its dietary benefits and the great economic influence from companies. Regarding modifications, hydrolysis was the most popular because of its advantages over the functional properties of proteins. 


\subsection{International Regulations Associated with Modified Plant-Based Proteins}

Modified plant-based proteins are novel foods, subject to national and international regulations. Some places where specific regulations for novel foods (the category in which the modified plant-based proteins can lie) have been defined are the European Union, the United Kingdom, Canada, China, Australia, India, and Brazil [96]. Originally, a novel food in the European context was defined as food not consumed by humans in the European Union widely before 15 May 1997 [97]. In addition, novel food can also be defined as when a production process was not employed before 15 May 1997, in the European Union for obtaining food [98]. In Figure 3, a summary of the main aspects to consider when classifying a product as novel food can be found.

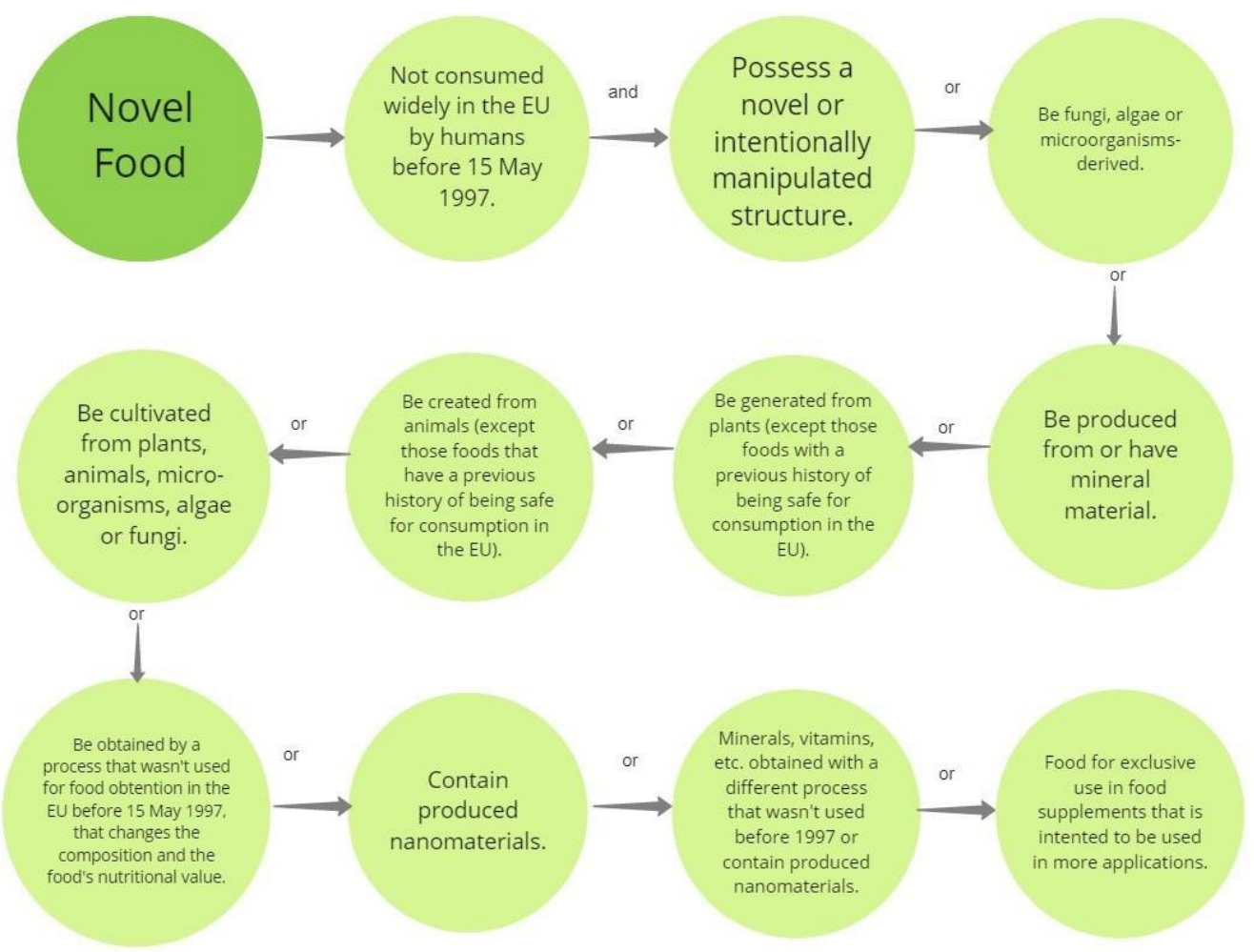

Figure 3. Aspects to consider applying the term "novel food". Information retrieved from [98].

In the European Union, Regulation (EC) No 258/97 laid the groundwork as regards legislation to make sure that all novel foods and novel food ingredients are safe for consumers $[98,99]$. Basically, this was the first regulation regarding novel foods that came into place in the European Union, and it established what a novel food was [99]. In 2015, Regulation (EU) 2015/2283 came into effect to replace both Regulation (EC) No 258/97 and (EC) No 1852/2001 to ease the authorization methods and address the newest developments in regulations, as well as in technology [98]. In this new regulation, a classification for novel food, with either an original or modified structure on purpose, was defined [98]. Furthermore, it was also established that if a novel food pretends to supplant an existing one, it should offer similar nutritional benefits for the people that will ingest it [98].

In addition, novel technologies to create food are preferred because they may offer a way to diminish the environmental impact of food elaboration and increase food security [98]. For a novel food to be approved in Europe, it should be safe for human consumption, not be misleading to the people, and, if it intends to replace an existing food, it should not differ widely from the first (in terms of nutritional value) [98]. Whoever wants their novel food to be able to be sold in the European market should fill in an application with detailed information, such as the name and address of the applicant, title and description of their innovation, how to produce it, the components of their food, scientific 
proof that shows its safety for humans, analysis techniques (if applicable) and a suggestion for what the label might need in order to not confuse the customer (or if it is the case, an explanation of why it will not be needed) [98]. After evaluation, in a maximum of seven months, the commission sets a list of novel foods that possess authorization to be on the European market [98].

In Australia, "Standard 1.5.1 Novel Foods" describes a novel food as a type that needs evaluation for its possible implications in human health, considering aspects like how this food is prepared, its structure, and its origin [100].

Canada is another country that has already set regulations for novel foods, where division 28 of "Food and Drug Regulations" is devoted to novel foods [101]. Here, a novel food has been described as (1) A compound that does not possess a previous history of usage as food, (2) A food whose production process was not used before to obtain it (this production process causes a change, i.e., causes a variation on its composition, how the body metabolizes it or the safety of the product differs from what is already present), (3) A food whose origin can be from microorganisms, animals, or plants that can either show or no longer show aspects that were formerly described in that species [101]. Regarding market authorization, the manufacturer must send a written note to the Minister where information like the name of the novel food and a description (the method used to produce it) are included [101]. After receiving this information, the Minister reviews it in forty-five days (maximum) to ensure that the product is safe to consume [101]. In case the Minister needs more information to review that a novel food is safe, they could ask the manufacturer to provide it [101]. In ninety days after the supplementary information is provided, the Minister must review it and tell the manufacturer if it is enough [101].

To conclude, the previously mentioned regulations similarly define the term "novel food", which is a food that can be dangerous because it has not been consumed before and therefore should be assessed [96]. Some countries have a general procedure for the manufacturers to submit their applications for new products (none of them have a specific procedure for modified proteins). Since the same procedure applies to many countries in the European Union, it is well known and established. However, some countries do not have regulations for these types of products.

\section{Conclusions and Future Trends}

The incorporation of plant-based proteins in food applications is increasing. Therefore, it must be prioritized that this type of protein can be employed. Chemical modifications prove to be an effective way of making this come true, by enhancing the solubility and other functional properties, such as the emulsifying capacity and foaming capacity.

From the revised works, 13 out of 24 enzymatic hydrolyses were chosen to chemically modify protein isolates. Furthermore, regarding the kind of plant-based protein that was mainly chosen, in 13 of those works (which represents 54.2\%) legumes were selected $[21,22,25,27,28,30,32-34,36,38,42,65]$. This number was followed by oilseeds used in four of the revised works $(16.7 \%)[25,29,35,37]$. Edible seeds, nuts and other sources accounted for $25 \%$ of the total (divided equally into 3 groups, i.e., each one represented $8.3 \%$ ) $[31,39,40,44-46]$. Last but not least, tubers represented $4 \%$ of the reviewed works [41].

To assess the quality of modified plant-based proteins, an evaluation using PER, the initial idea of how good a protein is, can be obtained. Although PDCAAS is still used, DIAAS should be preferred since evaluating the digestibility of amino acids in the ileum provides a more realistic idea of how good a protein is for human consumption. Furthermore, chemical modification is a helpful method to reduce the number of antinutritional factors. Therefore, determining amino acid profiles must be prioritized in chemically modified proteins to evaluate whether these novel foods can be incorporated into human diets.

Regarding the patents, 18 out of 23 used hydrolysis to chemically modify the proteins (representing 78.26\% of the total). China and the United States of America are the leading countries where novel processes and products related to modified plant-based proteins are being patent-protected, which may be related to the fact that these are the two leading 
global economies. There is also a clear trend in modifying soy protein to enhance its properties because it possesses amino acids that human beings are incapable of synthesizing. Companies also exert pressure to obtain proteins that can be incorporated into food systems that contain a complete amino acid profile. Indeed, industrial byproducts rich in protein should be explored to determine if they hold any value for the industry, and, if so, how to modify them so that they can be incorporated into food applications. More resources will likely be dedicated to exploring the modification of proteins in the next few years because the population is growing, and needs will be greater.

Author Contributions: Conceptualization, G.L.H.-L., L.M.M. and C.C.-H.; validation, L.M.M. and C.C.-H.; investigation, G.L.H.-L.; writing-original draft preparation, G.L.H.-L., L.M.M. and C.C.-H.; writing-review and editing, L.M.M. and C.C.-H. All authors have read and agreed to the published version of the manuscript.

Funding: This research received no external funding.

Institutional Review Board Statement: Not applicable.

Informed Consent Statement: Not applicable.

Data Availability Statement: Not applicable.

Acknowledgments: The authors acknowledge the support of the Sciences Department of the School of Engineering and Sciences in Tecnológico de Monterrey.

Conflicts of Interest: The authors declare no conflict of interest.

\section{References}

1. Quesada, D.; Gómez, G. ¿Proteínas de origen vegetal o de origen animal?: Una mirada a su impacto sobre la salud y el medio ambiente. Rev. Nutr. Cliacute Nica Metab. 2019, 2, 79-86. [CrossRef]

2. Bessada, S.M.F.; Barreira, J.C.S.; Oliveira, M.B.P.P. Pulses and food security: Dietary protein, digestibility, bioactive and functional properties. Trends Food Sci. Technol. 2019, 93, 53-68. [CrossRef]

3. Pasiakos, S.M.; Agarwal, S.; Lieberman, H.R.; Fulgoni, V.L. Sources and Amounts of Animal, Dairy, and Plant Protein Intake of US Adults in 2007-2010. Nutrients 2015, 7, 7058-7069. [CrossRef] [PubMed]

4. WHO/FAO/UNU. Protein and Amino Acid Requirements in Human Nutrition. In WHO Technical Report Series; World Health Organization (WHO): Geneva, Switzerland, 2007; Volume 935. Available online: http:/ /apps.who.int/iris/bitstream/handle/10665/ 43411/WHO_TRS_935_eng.pdf;jsessionid=FBAA23594A12472792868A699011A48D?sequence=1 (accessed on 27 December 2021).

5. Soria-Hernández, C.; Serna-Saldivar, S.; Chuck-Hernández, C. Physicochemical and Functional Properties of Vegetable and Cereal Proteins as Potential Sources of Novel Food Ingredients. Food Technol. Biotechnol. 2015, 53, 269-277. [CrossRef] [PubMed]

6. Rubilar, M.; Gutiérrez, C.; Verdugo, M.; Shene, C.; Sineiro, J. Flaxseed as a source of functional ingredients. J. Soil Sci. Plant Nutr. 2010, 10, 373-377. [CrossRef]

7. Arya, S.S.; Salve, A.R.; Chauhan, S. Peanuts as functional food: A review. J. Food Sci. Technol. 2016, 53, 31-41. [CrossRef]

8. Panghal, A.S.U.; Khatkar, B.S.; Singh, U. Cereal proteins and their role in food industry. Indian Food Ind. 2006, $25,58-62$.

9. Monti, L.M.; Grillo, S. Legume seed improvement for protein content and quality. Qual. Plant. Plant Foods Hum. Nutr. 1983, 32, 253-266. [CrossRef]

10. Angeli, V.; Silva, P.M.; Massuela, D.C.; Khan, M.W.; Hamar, A.; Khajehei, F.; Graeff-Hönninger, S.; Piatti, C. Quinoa (Chenopodium quinoa Willd.): An Overview of the Potentials of the "Golden Grain" and Socio-Economic and Environmental Aspects of Its Cultivation and Marketization. Foods 2020, 9, 216. [CrossRef]

11. Bártova, V.; Bárta, J.; Diviš, J.; Švajner, J.; Peterka, J. Crude protein content in tubers of starch processing potato cultivars in dependence on different agro-ecological crude protein content in tubers of starch processing potato cultivars in dependence on different agro-ecological conditions. J. Cent. Eur. Agric. 2009, 10, 57-66.

12. Nasrabadi, M.N.; Doost, A.S.; Mezzenga, R. Modification approaches of plant-based proteins to improve their techno-functionality and use in food products. Food Hydrocoll. 2021, 118, 106789. [CrossRef]

13. Shahbandeh, M. Forecast Value of the Protein Ingredients Market Worldwide from 2020 to 2025 (in Billion U.S. Dollars). 2021. Available online: https://www.statista.com/statistics/1177892/global-plant-based-protein-market-value/ (accessed on 27 December 2021).

14. Shahbandeh, M. Plant-Protein Market Value Worldwide from 2020 to 2026 (in Billion U.S. Dollars). 2021. Available online: https: / / www.statista.com/statistics / 658619/global-plant-protein-market-value/ (accessed on 27 December 2021).

15. Food and Agriculture Organization of the United Nations. Dietary protein quality evaluation in human nutrition. In Report of an FAO Expert Consultation; FAO: Rome, Italy, 2013. 
16. Maltais, M.L.; Leblanc, S.; Archambault-Therrien, C.; Jean, B.; Bobeuf, F.; Dionne, I.J. Various sources of animal protein intake and their association with muscle mass index and insulin resistance in overweight postmenopausal women. Int. J. Nutr. Metab. 2013, $5,17-21$.

17. Elmadfa, I.; Meyer, A.L. Animal Proteins as Important Contributors to a Healthy Human Diet. Annu. Rev. Anim. Biosci. 2017, 5, 111-131. [CrossRef]

18. Wouters, A.G.B.; Rombouts, I.; Fierens, E.; Brijs, K.; Delcour, J.A. Relevance of the Functional Properties of Enzymatic Plant Protein Hydrolysates in Food Systems. Compr. Rev. Food Sci. Food Saf. 2016, 15, 786-800. [CrossRef]

19. Espinoza-Herrera, J.; Martínez, L.M.; Serna-Saldívar, S.O.; Chuck-Hernández, C. Methods for the modification and evaluation of cereal proteins for the substitution of wheat gluten in dough systems. Foods 2021, 10, 118. [CrossRef]

20. Gruener, L.; Ismond, M.A.H. Effects of acetylation and succinylation on the physicochemical properties of the canola $12 \mathrm{~S}$ globulin. Food Chem. 1997, 60, 357-363. [CrossRef]

21. El-Adawy, T.A. Functional properties and nutritional quality of acetylated and succinylated mung bean protein isolate. Food Chem. 2000, 70, 83-91. [CrossRef]

22. Bora, P.S. Effect of acetylation on the functional properties of lentil (Lens culinaris) globulin. J. Sci. Food Agric. 2003, 83, 139-141. [CrossRef]

23. Kester, J.J.; Richardson, T. Modification of Whey Proteins to Improve Functionality. J. Dairy Sci. 1984, 67, 2757-2774. [CrossRef]

24. International Food Information Service. Dictionary of Food Science and Technology, 2nd ed.; IFIS Publishing: Reading, UK, 2009.

25. Lawal, O.S.; Adebowale, K.O.; Adebowale, Y.A. Functional properties of native and chemically modified protein concentrates from bambarra groundnut. Food Res. Int. 2007, 40, 1003-1011. [CrossRef]

26. Sun-Waterhouse, D.; Zhao, M.; Waterhouse, G.I.N. Protein Modification during Ingredient Preparation and Food Processing: Approaches to Improve Food Processability and Nutrition. Food Bioprocess Technol. 2014, 7, 1853-1893. [CrossRef]

27. Lawal, O.S.; Adebowale, K.O. Effect of acetylation and succinylation on solubility profile, water absorption capacity, oil absorption capacity and emulsifying properties of mucuna bean (Mucuna pruriens) protein concentrate. Food/Nahrung 2004, 48, 129-136. [CrossRef]

28. Mune, M.A.M.; Minka, S.R.; Mbome, I.L. Functional properties of acetylated and succinylated cowpea protein concentrate and effect of enzymatic hydrolysis on solubility. Int. J. Food Sci. Nutr. 2011, 62, 310-317. [CrossRef] [PubMed]

29. Miedzianka, J.; Zambrowicz, A.; Zielińska-Dawidziak, M.; Drożdż, W.; Nemś, A. Effect of Acetylation on Physicochemical and Functional Properties of Commercial Pumpkin Protein Concentrate. Molecules 2021, 26, 1575. [CrossRef] [PubMed]

30. Charoensuk, D.; Brannan, R.G.; Chanasattru, W.; Chaiyasit, W. Physicochemical and emulsifying properties of mung bean protein isolate as influenced by succinylation. Int. J. Food Prop. 2018, 21, 1633-1645. [CrossRef]

31. Ramos, C.M.P.; Bora, P.S. Functionality of Succinylated Brazil Nut (Bertholletia excelsa HBK) Kernel Globulin. Plant Foods Hum. Nutr. 2005, 60, 1-6. [CrossRef] [PubMed]

32. Arteaga, V.G.; Guardia, M.A.; Muranyi, I.; Eisner, P.; Schweiggert-Weisz, U. Effect of enzymatic hydrolysis on molecular weight distribution, techno-functional properties and sensory perception of pea protein isolates. Innov. Food Sci. Emerg. Technol. 2020, 65, 102449. [CrossRef]

33. Barac, M.; Cabrilo, S.; Stanojevic, S.; Pesic, M.; Pavlicevic, M.; Zlatkovic, B.; Jankovic, M. Functional properties of protein hydrolysates from pea (Pisum sativum L.) seeds. Int. J. Food Sci. Technol. 2012, 47, 1457-1467. [CrossRef]

34. Schlegel, K.; Sontheimer, K.; Hickisch, A.; Wani, A.A.; Eisner, P.; Schweiggert-Weisz, U. Enzymatic hydrolysis of lupin protein isolates-Changes in the molecular weight distribution, technofunctional characteristics, and sensory attributes. Food Sci. Nutr. 2019, 7, 2747-2759. [CrossRef]

35. Chabanon, G.; Chevalot, I.; Framboisier, X.; Chenu, S.; Marc, I. Hydrolysis of rapeseed protein isolates: Kinetics, characterization and functional properties of hydrolysates. Process Biochem. 2007, 42, 1419-1428. [CrossRef]

36. Ghribi, A.M.; Gafsi, I.M.; Sila, A.; Blecker, C.; Danthine, S.; Attia, H.; Bougatef, A.; Besbes, S. Effects of enzymatic hydrolysis on conformational and functional properties of chickpea protein isolate. Food Chem. 2015, 187, 322-330. [CrossRef]

37. Demirhan, E.; Özbek, B. Influence of Enzymatic Hydrolysis on the Functional Properties of Sesame Cake Protein. Chem. Eng. Commun. 2013, 200, 655-666. [CrossRef]

38. María, D.Y.M.; Pedroche, J.; Del Millán-Linares, M.; Alcaide-Hidalgo, J.M.; Millán, F. Improvement of functional properties of chickpea proteins by hydrolysis with immobilised Alcalase. Food Chem. 2010, 122, 1212-1217.

39. Phongthai, S.; Singsaeng, N.; Nhoo-Ied, R.; Suwannatrai, T.; Schönlechner, R.; Unban, K.; Klunklin, W.; Laokuldilok, T.; Phimolsiripol, Y.; Rawdkuen, S. Properties of Peanut (KAC431) Protein Hydrolysates and Their Impact on the Quality of Gluten-Free Rice Bread. Foods 2020, 9, 942. [CrossRef]

40. Trigui, I.; Yaich, H.; Sila, A.; Cheikh-Rouhou, S.; Krichen, F.; Bougatef, A.; Attia, H.; Ayadi, M.A. Physical, techno-functional and antioxidant properties of black cumin seeds protein isolate and hydrolysates. J. Food Meas. Charact. 2021, 15, 3491-3500. [CrossRef]

41. Galves, C.; Galli, G.; Miranda, C.G.; Kurozawa, L.E. Improving the emulsifying property of potato protein by hydrolysis: An application as encapsulating agent with maltodextrin. Innov. Food Sci. Emerg. Technol. 2021, 70, 102696. [CrossRef]

42. Lamsal, B.P.; Jung, S.Ã.; Johnson, L.A. Rheological properties of soy protein hydrolysates obtained from limited enzymatic hydrolysis. LWT 2007, 40, 1215-1223. [CrossRef] 
43. Toma, M.R.S.; Betancur-Ancona, L.C.D. Functional and bioactive properties of Velvet bean (Mucuna pruriens) protein hydrolysates produced by enzymatic treatments. J. Food Meas. Charact. 2014, 8, 61-69.

44. Li, X.; Deng, J.; Shen, S.; Li, T.; Yuan, M.; Yang, R.; Ding, C. Antioxidant activities and functional properties of enzymatic protein hydrolysates from defatted Camellia oleifera seed cake. J. Food Sci. Technol. 2015, 52, 5681-5690. [CrossRef]

45. Fathollahy, I.; Farmani, J.; Kasaai, M.R.; Hamishehkar, H. Characteristics and functional properties of Persian lime (Citrus latifolia) seed protein isolate and enzymatic hydrolysates. LWT 2020, 140, 110765. [CrossRef]

46. Zhao, G.; Liu, Y.; Zhao, M.; Ren, J.; Yang, B. Enzymatic hydrolysis and their effects on conformational and functional properties of peanut protein isolate. Food Chem. 2011, 127, 1438-1443. [CrossRef]

47. Zayas, J.F. Solubility of Proteins. In Functionality of Proteins in Food; Springer: Berlin/Heidelberg, Germany, 1997.

48. Thiansilakul, Y.; Benjakul, S.; Shahidi, F. Compositions, functional properties and antioxidative activity of protein hydrolysates prepared from round scad (Decapterus maruadsi). Food Chem. 2007, 103, 1385-1394. [CrossRef]

49. Flickinger, M.C. Encyclopedia of Industrial Biotechnology, Bioprocess, Bioseparation, and Cell Technology; John Wiley: Hoboken, NJ, USA, 2010; Volumes 1-7.

50. Gehring, C.K.; Davenport, M.P.; Jaczynski, J. Functional and Nutritional Quality of Protein and Lipid Recovered from Fish Processing by-Products and Underutilized Aquatic Species Using Isoelectric Solubilization/Precipitation. Curr. Nutr. Food Sci. 2009, 5, 17-39. [CrossRef]

51. Shilpashree, B.G.; Arora, S.; Chawla, P.; Tomar, S.K. Effect of succinylation on physicochemical and functional properties of milk protein concentrate. Food Res. Int. 2015, 72, 223-230. [CrossRef]

52. Maehashi, K.; Huang, L. Bitter peptides and bitter taste receptors. Cell. Mol. Life Sci. 2009, 66, 1661-1671. [CrossRef] [PubMed]

53. Yuliana, M.; Thanh, C.; Huong, L.; Phong, Q.; Ju, Y. Isolation and characterization of protein isolated from defatted cashew nut shell: Influence of $\mathrm{pH}$ and $\mathrm{NaCl}$ on solubility and functional properties. LWT-Food Sci. Technol. 2014, 55, 621-626. [CrossRef]

54. Vihinen, M. Solubility of proteins. ADMET 2020, 8, 391-399. [CrossRef]

55. Aguilar, V.; Vélez, J. Propiedades nutricionales y funcionales del garbanzo (Cicer arietinum L.). Carbohidratos 2013, 7, 27-30.

56. Boye, J.; Zare, F.; Pletch, A. Pulse proteins: Processing, characterization, functional properties and applications in food and feed. Food Res. Int. 2010, 43, 414-431. [CrossRef]

57. Zayas, J.F.; Lin, C.S. Emulsifying Properties of Corn Germ Proteins. Cereal Chem. 1989, 66, 263-267.

58. Qamar, S.; Manrique, Y.J.; Parekh, H.; Falconer, J.R. Nuts, cereals, seeds and legumes proteins derived emulsifiers as a source of plant protein beverages: A review. Crit. Rev. Food Sci. Nutr. 2020, 60, 2742-2762. [CrossRef]

59. Deotale, S.; Dutta, S.; Moses, J.A.; Balasubramaniam, V.M.; Anandharamakrishnan, C. Foaming Characteristics of Beverages and Its Relevance to Food Processing. Food Eng. Rev. 2020, 12, 229-250. [CrossRef]

60. Gomes, A.; Sá, A.; Maria, Y.; Moreno, F.; Augusto, B. Food processing for the improvement of plant proteins digestibility. Crit. Rev. Food Sci. Nutr. 2020, 60, 3367-3386.

61. Falcão, L.; Araújo, M.E.M. Vegetable Tannins Used in the Manufacture of Historic Leathers. Molecules 2018, 23, 1081. [CrossRef]

62. Chung, K.-T.; Wong, T.Y.; Wei, C.-I.; Huang, Y.-W.; Lin, Y. Tannins and Human Health: A Review. Crit. Rev. Food Sci. Nutr. 1998, 38, 421-464. [CrossRef]

63. González-Torres, L.; Téllez-Valencia, A.; Sampedro, J.G. Las proteínas en la nutrición. Rev. Salud Pública Nutr. $2007,8,1-7$.

64. Wolfe, R.R.; Baum, J.I.; Starck, C.; Moughan, P.J. Factors contributing to the selection of dietary protein food sources. Clin. Nutr. 2018, 37, 130-138. [CrossRef]

65. Kumar, M.; Tomar, M.; Potkule, J.; Reetu; Punia, S.; Dhakane-Lad, J.; Singh, S.; Dhumal, S.; Pradhan, P.C.; Bhushan, B.; et al. Functional characterization of plant-based protein to determine its quality for food applications. Food Hydrocoll. 2020, 123, 106986. [CrossRef]

66. Marinangeli, C.P.F.; House, J.D. Potential impact of the digestible indispensable amino acid score as a measure of protein quality on dietary regulations and health. Nutr. Rev. 2017, 75, 658-667. [CrossRef]

67. Huang, S.; Wang, L.M.; Sivendiran, T.; Bohrer, B.M. Review: Amino acid concentration of high protein food products and an overview of the current methods used to determine protein quality. Crit. Rev. Food Sci. Nutr. 2018, 58, 2673-2678. [CrossRef]

68. Mathai, J.K.; Liu, Y.; Stein, H.H. Values for digestible indispensable amino acid scores (DIAAS) for some dairy and plant proteins may better describe protein quality than values calculated using the concept for protein digestibility-corrected amino acid scores (PDCAAS). Br. J. Nutr. 2017, 117, 490-499. [CrossRef] [PubMed]

69. Vázquez, R.S.; Cervantes, P.P.; López, R.J. ¿Qué sabe usted acerca de ... propiedad intelectual farmacéutica? What do you know about ... intellectual property pharmaceutical? Rev. Mex. Cienc. Farm. 2015, 46, 77-79.

70. Van Koeveringe, L.; Haaf, K.T. Vegetable Protein Hydrolysis. Patent ES2535985T3, 19 March 2015.

71. Janse, A.M.C.; Veerman, C.; Smolders, G.J.F. The Mild Hydrolysis of Protein from Rice Bran. Patent CN104754955B, 19 June 2018.

72. Abramyan, A.; Afanasyev, M.; Beklemyshev, V.; Fillipov, K.; Makhonin, I.; Maugeri, U. Hygienic Product with Antimicrobic and Antifunguses Properties. Patent WO2011/107311A1, 9 September 2011.

73. Capezza, A.; Newson, W.; Olson, R.; Hedenqvist, M. Method of Preparing Plant Protein Based Absorbent Material and Absorbent Material thus Produced. Patent WO2020/251467A1, 17 November 2020.

74. Laplante, T.; Pham, S.; Patel, N.; Konuklar, G. Method of Manufacturing a Nutritional Powder with In Situ Protein Hydrolysis. Patent WO2018/125920A1, 5 March 2018. 
75. Tsumura, K.; Nakamura, K.; Kugimiya, Y.; Miyazaki, W.; Kuramori, T. Soybean Protein Hydrolysates, Their Production and Use. Patent EP0976331B1, 26 May 2003.

76. Gajadeera, C.; Ismail, B.; Mortenson, M.A.; Porter, M.A. Corn Protein Hydrolysates and Methods of Making. Patent CA3118136A1, 7 March 2020.

77. Hwang, D.; Shah, N.; Kerr, P.; Wong, T.; Lynglev, G. Protein Hydrolysate Compositions. Patent EP2384124B1, 16 September 2015.

78. Coleman, E.; May, G. Protein System and Food Products Including Same. Patent CN104336619A, 11 February 2015.

79. Louis, S.T. Soy Protein Isolate Composition Having Improved Functionality. U.S. Patent 2006/0228463A1, 12 October 2006.

80. Melnychyn, P.; Stapley, R.B. Acylated Protein for Coffee Whitener Formulations. U.S. Patent 3,764,711, 9 October 1973.

81. Hamm, D.J. A Process for the Production of Hydrolyzed Vegetable Proteins Using Gaseous Hydrochloric Acid and the Product Therefrom. Patent EP0495391A1, 8 April 1998.

82. Cuenca, L.; Rowena, C.; Alvarez, F.; Dee, K. Hydrolyzed Vegetable Protein Liquid Compositions. Patent US20050025877A1, 3 February 2005.

83. Park, E.; May, W.A. Method for Producing a Savory Flavor Base. U.S. Patent 6,251,443B1, 26 June 2001.

84. Stiles, A.; Homyak, C.; Astor, S.; Smith, B. Non-Dairy Analogs with Succinylated Plant Proteins and Methods of Using Such Products. Patent CN113163782A, 23 July 2019.

85. Berends, P.; Fischer, L.; Linke, D.; Rabe, S.; Gunter, R. Plant Protein Hydrolysates. Patent EP2468109A1, 27 June 2012.

86. Shuntang, G.; Yangling, W.; Shiwen, G.; Xiaodi, S.; Guanghua, Z. Fishy Smell-Free High-Emulsibility Isolated Soy Protein and Preparation Method Thereof. Patent CN108041254B, 28 July 2017.

87. Yang, Q.; Yu, L.; Zhang, H.; Zhu, F.; Sun, J.; Bi, J.; Zhang, C. Preparation Method for Enzyme-Modified Peanut Protein. Patent CN102334588B, 3 April 2011.

88. Brown, J.A.; Wong, T.M.; Staerk, D.U.; Rose, C.; Saraia, I.; McKeague, D.M.; Wang, Z. Non-Dairy Creamers Comprising Protein Hydrolysate Compositions and Method for Producing the Non-Dairy Creamers. U.S. Patent 20110236545A1, 29 September 2011.

89. Duan, G.; Jacobsen, K.; Shetty, J.; Ying, Q. Method of Making a Snack Bar Comprising a Low Temperature Rice Protein Concentrate. Patent EP2608682B1, 13 December 2017.

90. Ventureira, J. Soluble Legume Protein. Patent WO2020/109741A1, 4 June 2020.

91. De Sadeleer, J.; Karleskind, D.; Mccrae, C.; Meheus, E. Partially Hydrolysed Cereal Protein. U.S. Patent 9,259,018B2, 16 February 2016.

92. Xia, H.; Merkel, M.W.; Unlu, E.; Abts, S.L.; Mathewson, P.R.; Danset, G.L.D.; Yonemoto, L. Food Protein Ingredient and Methods For Producing. U.S. Patent 2013/0209611A1, 17 April 2013.

93. Browmik, T.; Simons, C.; Myaka, S. Fermented Ingredient. U.S. Patent 9,693,576B2, 4 July 2017.

94. Oliver, L.G.; Sánchez, R.G. Las cuatro grandes empresas comercializadoras y los precios internacionales de los alimentos. Econ. Inf. 2016, 400, 24-39. [CrossRef]

95. Michelfelder, A.J. Soy: A complete source of protein. Am. Fam. Physician 2009, 79, $43-47$.

96. Knezevic, N.; Grbavac, S.; Palfi, M.; Sabolović, M.B.; Brnčić, S.R. Novel food legislation and consumer acceptance-Importance for the food industry, Emirates. J. Food Agric. 2021, 33, 93.

97. Ruffell, M.J. Authorised EU heaslth claim for foods with a low or reduced content of sodium. In Foods, Nutrients and Food Ingredients with Authorised EU Health Claims; Elsevier: Amsterdam, The Netherlands, 2015; Volume 2, pp. 275-298.

98. European Parliament and the Council of the European Union. Regulation (EU) 2015/2283 of the European Parliament and of Council on novel foods, amending Regulation (EU) No 1169/2011 of the European Parliament and of the Council and repealing Regulation (EC) No 258/97 of the European Parliament and of the Council and Commission Regulation (EC) No 1852/2001. Off. J. Eur. Union 2015, 327, 1-22.

99. European Parliament and the Council of the European Union. Regulation (EC) No 258/97 of the European Parliament and of the Council of 27 January 1997 concerning novel foods and novel food ingredients. Off. J. Eur. Communities 1997, 40, 1-6.

100. Australian Government. Standard 1.5.1 Novel Foods. 2017. Available online: https://www.legislation.gov.au/Details/F2017C0 0324 (accessed on 27 December 2021).

101. Minister of Justice. Food and Drug Regulations-Canada. Available online: https://www.canada.ca/en/health-canada/services/ food-nutrition/legislation-guidelines/acts-regulations/canada-food-drugs.html (accessed on 27 December 2021). 